\title{
Endocrine Disruptors and Autism Spectrum Disorder in Pregnancy: A Review and Evaluation of the Quality of the Epidemiological Evidence
}

\author{
Salvador Marí-Bauset ${ }^{1}$, Carolina Donat-Vargas ${ }^{2}$, Agustín Llópis-González ${ }^{1,3}$, \\ Amelia Marí-Sanchis ${ }^{4}$, Isabel Peraita-Costa ${ }^{1,3}$, Juan Llopis-Morales ${ }^{1}$ and \\ María Morales-Suárez-Varela $1,3, *$ D \\ 1 Unit of Public Health and Environmental Care, Department of Preventive Medicine, University of Valencia, \\ Avenida Vicente Andrés Estellés s/n, Burjasot, 46100 Valencia, Spain; salvador.mari@ext.uv.es (S.M.-B.); \\ agustin.llopis@uv.es (A.L.-G.); ivperaitacosta@hotmail.es (I.P.-C.); juanllopis6@gmail.com (J.L.-M.) \\ 2 Nutritional Epidemiology, Institute of Environmental Medicine, Karolinska Institutet, Nobels väg 13, \\ 17165 Solna, Sweden; carolina.donat.vargas@ki.se \\ 3 Biomedical Research Center Network on Epidemiology and Public Health (CIBERESP), Institute of Health \\ Carlos III, Avenida Monforte de Lemos, 3-5, Pabellón 11, Planta 0, 28029 Madrid, Spain \\ 4 Clinical Nutrition and Dietetics Unit, Navarra Hospital Complex, Calle de Irunlarrea, 3, Pamplona, \\ 31008 Navarre, Spain; amarisanchis@gmail.com \\ * Correspondence: maria.m.morales@uv.es; Tel.: +34-96-3544951
}

Received: 21 October 2018; Accepted: 19 November 2018; Published: 23 November 2018

\begin{abstract}
Exposure to environmental contaminants during pregnancy has been linked to adverse health outcomes later in life. Notable among these pollutants are the endocrine disruptors chemicals (EDCs), which are ubiquitously present in the environment and they have been measured and quantified in the fetus. In this systematic review, our objective was to summarize the epidemiological research on the potential association between prenatal exposure to EDCs and Autism Spectrum Disorder (ASD) published from 2005 to 2016. The Navigation Guide Systematic Review Methodology was applied. A total of 17 studies met the inclusion criteria for this review, including: five cohorts and 12 case-control. According to the definitions specified in the Navigation Guide, we rated the quality of evidence for a relationship between prenatal exposure to EDCs and ASD as "moderate". Although the studies generally showed a positive association between EDCs and ASD, after considering the strengths and limitations, we concluded that the overall strength of evidence supporting an association between prenatal exposure to EDCs and later ASD in humans remains "limited" and inconclusive. Further well-conducted prospective studies are warranted to clarify the role of EDCs on ASD development.
\end{abstract}

Keywords: autism; ASD; child behavior disorders; endocrine disruptor; environmental exposure

\section{Introduction}

Autism spectrum disorders (ASD) comprise a complex set of behaviorally defined neurodevelopmental abnormalities in two core areas: deficits in social communication and fixated, restricted, repetitive, or stereotyped behaviors and interests. Prevalence of ASD has significantly increased globally over the last few decades [1-3], and today it is estimated to be between 6.2 and 7.6 per 1000 persons [4,5]. ASD prevalence reported in the United States (US) reached 14.7 per 1000 (i.e., 1 in 68) in children aged eight years [6]. On the other hand, Christensen et al., (2016) describe ASD prevalence among four-year-old children in 5 of 11 sites participating in the 2010 Autism 
and Developmental Disabilities Monitoring Network as 13.4 per 1000, which was $30 \%$ lower than eight-year-old ASD prevalence, and the male-to-female ratio is nearly 5:1 [7,8].

\subsection{Environmental Factors and ASD Causation}

So far, the study of the etiology of ASD has focused mainly on identifying specific ASD risk genes $[9,10]$. Studies on the concordance of autism diagnosis between identical twins and among siblings have indicated a strong genetic component contributing to ASD [11,12]. Hallmayer et al., (2011) [13] in their study found that only 38\% of ASD cases were attributable to genetic causes. However, studies examining the concordance rates between monozygotic twins revealed that although the concordance rate of ASD between monozygotic twins was higher than of dizygotic twins, the penetrance was still partial, revealing that genetic factors alone do not explain all of the pathogenicity and variability in ASD [14].

Findings like those aforementioned, together with the rapidly increasing prevalence of ASD, has led to recognize that environmental factors may play a significant role in the etiology and pathogenesis of ASD [15-17]. Gene-environment interactions during fetal development leading to early-life epigenetic changes are also known to affect subsequent gene expression in the brain [18], and to be behind the potential risk of ASD following the prenatal exposure to environmental factors [2,19-27]. Epigenetic modifications (the alteration of DNA transcription without alterations in the DNA sequence) affect gene regulation. These alterations in gene expression result from transcriptional regulatory influences of environmental factors, such as immunological effects, nutritional deficiencies, endocrine disruptors chemicals (EDCs), and pharmaceuticals [28].

\subsection{EDCs and Human Exposure}

Close to 800 chemicals are known or suspected to be capable of interfering the function(s) of the endocrine system. However, only a small fraction of these chemicals have been investigated are now beginning to be recognized as potential threats to health [29-31]. Some of these chemicals have the capacity to interfere with the endocrine system mimicking the action of endogenous hormones; antagonizing their mechanism of action; altering their pattern of synthesis, transport, release, or metabolism; or, by modulating the levels of the corresponding receptors [31]. The endocrine disruptor chemicals (EDCs) include a huge variety of human purposefully created chemicals with commercial, agricultural, industrial, or pharmaceutical applications. EDCs migrate into the air, food, and water of humans and wildlife. They are also incorporated into numerous products that are used in daily life (e.g., plastics, furniture, pesticides, cosmetics, drugs, household products, or even food), as well as in processes of combustion of fossil fuels, among others; and consequently, human exposure to EDCs may come from numerous sources.

They include bisphenol-A (BPA) and its structural analogs (e.g., BFS, BPF), phthalates, brominated flame retardants, perfluorate compounds, aromatic polycyclic hydrocarbons, dichlorodiphenyl trichloroethane (DDT), polychlorinated biphenyls (PCB), and some heavy metals [20,31-35], as summarized in Table 1. Their physicochemical properties, such as persistence, stability, and bioaccumulation capacity in the trophic chain varies greatly depending on the nature of compound. Thus, while some are very lipophilic, accumulate in the fatty tissue of living being and have long half-life (e.g., PCBs, dioxins, DDT), others are soluble in water (e.g., phthalates or biphenyl A), have a rapid excretion rate, and are not bioaccumulative (e.g., phthalates, BPA). However, low level exposure maintained over time to these hydrophilic EDCs, with less bioaccumulative potential and shorter half-life in the human bodies have been also associated with neurodevelopmental disorders [31,36,37]. 
Table 1. Chemical groups and subgroups of substances with endocrine disrupting potencial (Brouwers et al.,2009).

\begin{tabular}{|c|c|c|c|}
\hline Chemical Group & Subgroups & Description & Reported Endocrine Disrupting Effects \\
\hline $\begin{array}{l}\text { Polycyclic aromatic } \\
\text { hydrocarbons }\end{array}$ & None & Formed by incomplete combustion of carbon-containing fuels. & Anti-estrogenic effects in vitro \\
\hline $\begin{array}{l}\text { Polychlorinated organic } \\
\text { compounds }\end{array}$ & $\begin{array}{c}\text { Polychlorinated biphenyls (PCBs) } \\
\text { Dioxins, furans, polychlorinated naphthalene (PCN) } \\
\text { Hexachlorobenzene (HCB) } \\
\text { Octachlorostyrene (OCS) }\end{array}$ & $\begin{array}{l}\text { Produced as by-products during waste incineration and } \\
\text { industrial processes involving carbon and chlorine (eg., during } \\
\text { metal, solvent or pesticide manufacturing) PCBs: until 1970s } \\
\text { widely used as insulating and cooling fluids }\end{array}$ & $\begin{array}{l}\text { PCBs, dioxins, furans, PCN: interfere with steroid synthesis } \\
\text { through aryl hydrocarbon receptor binding; HCB: affects male } \\
\text { and female fertility in animal studies; OCS: their metabolites } \\
\text { possibly interfere with thyroid homeostasis through binding to } \\
\text { plasma proteins }\end{array}$ \\
\hline Pesticides & $\begin{array}{c}\text { Organochlorines } \\
\text { CarbamatesOrganophosphatesTributyltin } \\
\text { Pyrethroids } \\
\text { Other pesticides }\end{array}$ & $\begin{array}{l}\text { Used in agriculture.Other purposes include wood preservation, } \\
\text { anti-fouling, parasite treatment and public hygiene }\end{array}$ & $\begin{array}{c}\text { Estrogenic or anti-androgenic effects in vitro, reproductive } \\
\text { toxicity in animal models, and fertility or endocrine alterations } \\
\text { in human studies }\end{array}$ \\
\hline Phthalates & $\begin{array}{c}\text { Di-2-ethylhexyl phthalate (DEHP), di-isononyl } \\
\text { phthalate (DNP), di-n-hexyl phthalate (DHP) } \\
\text { Benzylbutyl phthalate (BBP) } \\
\text { Dibutylphthalate(DBP) } \\
\text { Diethyl phthalate (DEP) }\end{array}$ & $\begin{array}{l}\text { Many industrial applications:High molecular weight } \\
\text { phthalates (DEHP, DNP, DHP) primarily used a plasticisers in } \\
\text { polyvinyl chloride(PVC).Low molecular weight phthalates } \\
\text { (BBP, DBP, DEP) used as solvents and plasticisers in cosmetics, } \\
\text { adhesives, ink, dyes and plastic packaging }\end{array}$ & $\begin{array}{l}\text { DEHP, DNP, DHP, BBP, DBP: affect the development of male } \\
\text { reproductive organs in animal studies; DEP, DBP, BBP: } \\
\text { suggested to interfere with male reproductive hormone levels } \\
\text { in children }\end{array}$ \\
\hline Organic solvents & $\begin{array}{l}\text { Ethylene glycol ethers (EGEs) } \\
\text { Styrene } \\
\text { 5oluene } \\
\text { Xylene } \\
\text { Trichloroethylene (TCE) } \\
\text { Perchloroethylene (PCE) }\end{array}$ & $\begin{array}{l}\text { EGEs, toluene, xylene: widely used in, for example, paints, } \\
\text { adhesives, thinners, lacquers and resinsStyrene: used for } \\
\text { producing polystyrene plastics and resinsTCE, PCE: used for } \\
\text { metal degreasing and other industrial cleaning purposes }\end{array}$ & $\begin{array}{l}\text { EGEs: reproductive toxicity in animal studies and possibly } \\
\text { associated with reduced fertility and menstrual length } \\
\text { variability in women; Styrene: styrene dimers and trimers bind } \\
\text { to estrogen receptors in vitro; Toluene, xylene, TCE: suggested } \\
\text { to interfere with reproductive hormone levels in humans. PCE: } \\
\text { dry cleaning has been associated with menstrual disorders, } \\
\text { infertility and delayed conception in women }\end{array}$ \\
\hline Bisphenol A & None & $\begin{array}{l}\text { Used in the production of polycarbonate plastic and } \\
\text { epoxy resins }\end{array}$ & Estrogenic effects according to in vitro and in vivo studies \\
\hline Alkylphenolic compounds & $\begin{array}{l}\text { Alkylphenolic ethoxylates (APEs) } \\
\text { Alkylphenols (APs) }\end{array}$ & $\begin{array}{l}\text { APEs: commonly used surfactants in, for example, detergents, } \\
\text { pesticides and cosmetics; APs: primarily used to produce APEs }\end{array}$ & $\begin{array}{l}\text { APE metabolites, which include APs and short chain APEs, } \\
\text { interact with estrogen receptors in vitro }\end{array}$ \\
\hline Flame retardants & $\begin{array}{l}\text { Tetrabromobisphenol A (TBBPA) } \\
\text { Hexabromocyclodecane (HBCD) } \\
\text { Polybrominated disphenyl ethe r(PBDEs) }\end{array}$ & $\begin{array}{l}\text { Widely used in the polymer industry, for example in the } \\
\text { production of PVC, epoxy resins, polyesteand rubber }\end{array}$ & $\begin{array}{l}\text { TBBPA, HBCD, PBDEs: interfere with thyroid hormone levels. } \\
\text { TBBPA, PBDEs: possibly interfere with estrogen metabolism } \\
\text { through estrogen sulfotransferase inhibition }\end{array}$ \\
\hline Metals & $\begin{array}{l}\text { Arsenic } \\
\text { Cadmium } \\
\text { Copper } \\
\text { Lead } \\
\text { Mercury }\end{array}$ & $\begin{array}{l}\text { E.g., used in the electrical/electronics industry, for construction, } \\
\text { in batteries, dyes, pesticides and dental amalgam, and as } \\
\text { chemical intermediates }\end{array}$ & $\begin{array}{c}\text { Arsenic: inhibits glucocorticoid gene transcription in vitro and } \\
\text { thought to have similar effects on other steroid receptors. } \\
\text { Cadmium, copper, lead, mercury: testicular toxicity in animal } \\
\text { models or altered hormone levels and/or male subfertility } \\
\text { in humans. }\end{array}$ \\
\hline Miscellaneous & $\begin{array}{l}\text { Benzophenones } \\
\text { Parabens } \\
\text { Siloxanes } \\
\text { Phytoestrgens } \\
\text { Pharmaceutical chemicals }\end{array}$ & $\begin{array}{l}\text { Benzophenones: UV screens used in cosmetics and the plastic } \\
\text { industry Parabens: widely used preservatives in cosmetics and } \\
\text { the pharmaceutical industry Siloxanes: intermediates in the } \\
\text { polymer industry and ingredients in personal care products } \\
\text { and precision cleaning agents } \\
\text { Soy and other plant products. }\end{array}$ & $\begin{array}{c}\text { Benzophenones: bind to estrogen receptors in vitro and exert } \\
\text { estrogenic effects in animal studies. } \\
\text { Parabens: estrogenic activity in vitro and in animal Studies. } \\
\text { Siloxanes: estrogenic and anti-estrogenic activity in } \\
\text { animal studies }\end{array}$ \\
\hline
\end{tabular}




\subsection{Prenatal EDC Exposure and Risk for ASD}

In 2012, the World Health Organization (WHO) and the United Nations Environment Programme (UNEP) defined EDCs as "exogenous substance or mixture that alters function(s) of the endocrine system and consequently causes adverse health effects in an intact organism, or its progeny, or (sub) populations" [31], expanding upon the concept of effects on subsequent generations (progeny).

Exposures in utero to even extremely low doses of EDCs during early development can alter sensitive biological processes, leading to permanent impairments in organ function [31,36-42]. The developing human brain is inherently much more susceptible to injury that is caused by toxic agents than is the brain of an adult. Specifically, the blood-brain barrier, which protects the adult brain from many toxic chemicals, is not completely formed until about six months after birth [43].

The most vulnerable and critical periods for toxic impact of pollutants on human development are the embryonic and fetal stages [44-46]. During fetal development, the placenta is not an effective barrier against most of the EDCs [47], which easily cross the placenta-around week 5 of embryo life, passing from the mother to the fetus [48]. EDCs concentrations in umbilical cord blood can be substantially higher than in maternal blood [49]. Moreover, the fetus has lower levels of several cytochrome P450 enzymes that metabolize environmental chemicals [50].

In ASD development, there is evidence that suggests than environmental exposures during these critical periods can permanently reprogram normal physiological responses (developmental reprogramming) in organogenesis and tissue differentiation [21,51-55]. Exposure to environmental chemicals during gestation has been associated with different neurodevelopmental disorders/deficits in children in both animal [56-58] and epidemiological studies [38-40,59-64].

The mechanisms by which EDCs act can range from gene expression to physiologic mechanisms, including steroid hormone receptor-mediated pathways. During pregnancy, the fetal brain has exquisite sensitivity to endogenous hormones from the mother and the fetus itself. These hormones, particularly steroid hormones, change the structure and function of the developing nervous system and their release is highly regulated, with very precise timing and levels needed to accomplish normal development [65]. The fact that ASD are approximately five times more prevalent in males than females has led some to propose a role of prenatal steroid hormone in the development of ASD [66]. Elevated fetal steroidogenic activity is associated with autistics traits $[67,68]$. It seems that the thyroid gland also play a key role in neurological fetal development $[69,70]$.

Thus, bisphenol A and its structural analogs has been linked to reductions of thyroxine (T4) and thyroid stimulating hormone (TSH) levels [71]. Phthalates has also been associated with lower levels of fT3 and fT4 as well as progesterone [72]. Nevertheless, the relationships between hormones, neurodevelopment, and the autistic phenotype are not clear.

Several molecular mechanisms plausibly explain how long-lasting effects of prenatally EDCs could affect brain and behavior. These mechanisms usually go under the heading epigenetic. Skinner et al. (2008) [73], in animal models showed that embryonic and fetal exposure to environmental contaminants led to changes in the expression of several genes in the brain through epigenetic pathways, as DNA methylation, RNA-associated silencing, and histone modifications. There is however much to comprehend yet.

In light of the correlation over decades between increasing industrial chemical production and increasing rates of ASD diagnoses, to assess the current state of epidemiological evidence on prenatal EDCs exposure and ASD risk supporting the suggested biological plausibility is warranted.

\section{Materials and Methods}

A systematic review of the medical literature was performed to address and understand the potential association between EDCs exposure during pregnancy and ASD in offspring. The question was asked: Is pregnancy exposure to endocrine disrupting chemicals associated with increased risk of ASD development? 


\subsection{Search Strategy}

The Navigation Guide Systematic Review Methodology [74,75]—adapted from Cochrane's methodology and the Grading of Recommendations Assessment Development and Evaluation (GRADE) Working Group [76-80] —was applied for synthesizing the available scientific evidence and for rating the quality and strength of the evidence across all the retrieved studies. The Navigation Guide, which is based on the PECO statement [81,82], is a novel evidence-based medicine method for a systematic and transparent environmental health reviews. This approach assigns a priori, a "moderate" quality rating to observational studies based on the characteristics of the studies and considering adjustments ("downgrades" or "upgrades"). Ratings for each criteria range from -2 ( 2 level downgrade) to +2 (2 level upgrade) and 0 indicating no change from "moderate" quality. As described in Table 2, while five factors (i.e., risk of bias for each included study, inconsistence between studies, indirectness, imprecision, and likely publication bias) may lead to rating down the quality of evidence, other three factors (i.e., large effect size, all potential confounding factors, and existent dose-response gradient) lead to rating up.

Table 2. Criteria for assigning quality and strength of evidence to observational studies (The Navigation Guide Systematic Review, Woodruff et al., 2011).

\begin{tabular}{|c|c|c|}
\hline Risk of Bias ${ }^{a}$ & Quality of Evidence ${ }^{b}$ & Strength of Evidence $b$ \\
\hline $\begin{array}{ll}\text { Domains: } \\
\text { - } \quad \text { Recruitment strategy } \\
\text { - } \quad \text { Blinding } \\
\text { - } \quad \text { Confunding } \\
\text { - } \quad \text { Exposure assessment } \\
\text { - } \quad \text { Outcome assessment } \\
\text { - } \quad \text { Incomplete outcome data } \\
\text { - } \quad \text { reported } \\
\text { - } \quad \text { Conflict of interest } \\
\text { - } \quad \text { Other bias } \\
\text { Evaluation: } \\
\text { Determined for each risk of bias domain } \\
\text { - } \quad \text { Low risk } \\
\text { - } \quad \text { Probably low risk } \\
\text { - } \quad \text { Probably high risk } \\
\text { - } \quad \text { High risk }\end{array}$ & $\begin{array}{l}\text { Human evidence begins as moderate } \\
\text { Downgrade criteria } \\
-1 \text { or }-2 \text { according these factors: } \\
\text { - } \quad \text { Risk of bias across studies } \\
\text { - Inconsistency of results } \\
\text { - } \quad \text { Indirectness of evidence } \\
\text { - Imprecision } \\
\text { - } \quad \text { Publication bias } \\
\text { Upgrade criteria } \\
+1 \text { or }+2 \text { according these factors: } \\
\text { - Large magnitude of effect } \\
\text { - } \quad \text { Dose response: Evidence of } \\
\text { - } \quad \text { all plausible confounding would } \\
\quad \text { confirm negative results }\end{array}$ & $\begin{array}{l}\text { The final rating represent the level of } \\
\text { certainty of toxicity. } \\
\text { Quality of body evidence: } \\
\text { - } \quad \text { Direction of effect } \\
\text { - } \quad \text { Confidence in effect } \\
\text { - } \quad \text { Other compelling attributes } \\
\text { of the data that may } \\
\text { influence certainty } \\
\text { Toxicity evidence rating } \\
\text { - } \quad \text { Sufficient } \\
\text { - } \quad \text { Limited } \\
\text { - Inadequate } \\
\text { - } \quad \text { Lack of toxicity }\end{array}$ \\
\hline
\end{tabular}

${ }^{a}$ Determined for each individual study; ${ }^{\mathrm{b}}$ Rated across all studies.

We assessed risk of bias using as guidance the Cochrane Collaboration's "Risk of Bias" tool and the Agency for Healthcare Research and Quality's (AHRQ) criteria, which includes selection bias, confounding, performance bias, attrition bias, detection bias, and reporting bias. At the risk of bias tool (internal validity), we contemplated the following domains: recruitment strategy, blinding, confounding, exposure/outcome assessments, incomplete outcome/exposure data, selection bias, conflict of interest, and other bias [83].

\subsection{Specify the Study Question}

This approach is developed around a PECO (participants, exposure, comparator, and outcomes) statement. The PECO statement was the guide for the whole review process, including the definition of the research question, the bibliographic search strategy (i.e., search terms, inclusion/exclusion criteria), the quality and strength criteria, as well as the strategy for the synthesis and report of the results. Based on statement we included the following:

- Participants: pregnant women and their children of any age. 
- Exposure: exposure to EDCs during pregnancy. The EDCs exposure was measured either through questionnaires/interviews held with parents, estimations provided by environmental agencies (Toxic Release Inventory (TRI), the US EPA National-scale Air Toxics Assessment (NATA), or analyses of biological samples.

- Comparator: works defined by ASD observational studies, and comparing the EDCs exposure levels for people with ASD versus those without.

- Outcomes: children of any age classified as having ASD disorder.

\subsection{Study Identification and Eligibility Criteria}

Following the Spanish National Health System recommendations, the search was based on Medline, although these other databases were also consulted: Cochrane Library, Scielo, Scopus, EMBASE, Google Scholar, PsychInfo, and Web of Science. Table 3 shows the search strategy using the following MeSH terms: Autism spectrum disorder, Autistic disorder, child behavior disorders, endocrine disruptors, environmental exposure, pesticides, pregnancy, prenatal, "in utero" with the corresponding Boolean operators.

Table 3. Search strategy.

\begin{tabular}{|c|c|}
\hline & Terms \\
\hline$\# 1$ & $\begin{array}{l}\text { "Autism spectrum disorder" }[\mathrm{MeSH}] \text { OR "Autistic disorder"[MeSH] OR “Child Development } \\
\text { Disorders, Pervasive"[Mesh] OR “Child Behavior Disorders"[Mesh] OR “ autistic traits" }\end{array}$ \\
\hline$\# 2$ & $\begin{array}{l}\text { "Environmental Exposure"[Mesh] OR "Endocrine Disruptors"[Mesh] OR "Pesticides"[Mesh] OR } \\
\text { "Polychlorinated Biphenyls"Mesh] OR "Hydrocarbons, Chlorinated"[Mesh] OR "Dichlorodiphenyl } \\
\text { Dichloroethylene"[Mesh] OR "DDT"[Mesh] OR "Hexachlorobenzene"[Mesh] OR "Flame } \\
\text { Retardants"[Mesh] OR "Polybrominated Biphenyls"[Mesh] OR "Perfluorooctane sulfonic acid" } \\
\text { [Supplementary Concept] OR "Bisphenol A" [Supplementary Concept] OR "Perfluorooctanoic acid" } \\
\text { [Supplementary Concept] }\end{array}$ \\
\hline \#3 & "pregnancy" OR "prenatal" OR “in utero" \\
\hline \#4 & $\# 1$ AND \#2 AND \#3 \\
\hline
\end{tabular}

Figure 1 provides the flow chart for the study selection process, based on the PRISMA flow [84-86]. Original articles published from 2005 to date were initially retrieved. The last search was made on May, 2017. The 2005 cutoff date was considered to be appropriate because the increasing ASD incidence of ASD registered $[6,87,88]$ as well as because the potential negative effects of EDCs have not been examined until recently. Equally, on several studies published after that date, the cohorts of children were actually born in the 1990s and early 2000s.

Inclusion criteria, based on PECO statement, were: (a) original articles; (b) observational (i.e., cohort, case-control and cross-sectional) studies; (c) only humans as study subjects without restriction of any demographic characteristics of the population; (d) exposure measured in women during pregnancy time period; (e) EDCs measured either (1) through questionnaires/interviews held with parents, (2) estimations provided by environmental agencies, or (3) analyses of biological samples; and, (f) the search was not restricted by language. Review articles, hypothesis papers, individual medical case studies, theses/dissertations, conference papers, and letters to the editor, as well as publications of animal models were excluded from this study. 

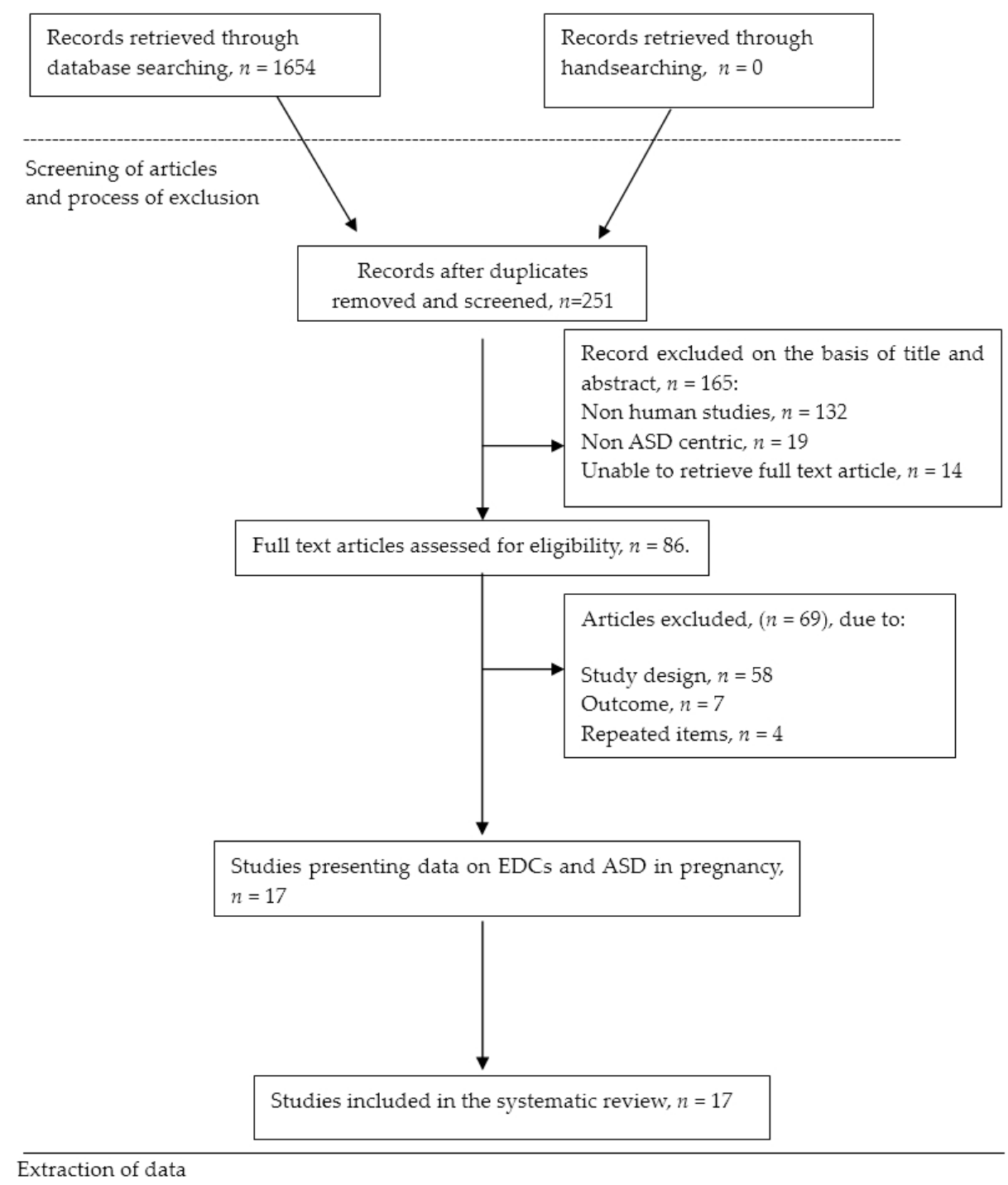

Figure 1. Flow chart of the systematic review process.

The evaluation of the risk of bias on the retrieved studies for the domain "outcome assessment" was based on the clinical criteria of diagnosis of ASD (Diagnostic and Statistical Manual of Mental Disorders (DSM) $[89,90]$ or the International Classification of Diseases (ICD). It was also taken into account if the data came from self-reports, direct observational assessment by a qualified clinician, or from record-based diagnoses from public agencies, such as the California Dept. of Developmental Services (DDS) or the Autism and Developmental Disabilities Monitoring (ADDM) Network. Additionally, this domain was evaluated for the risk of bias depending on the tool used on these articles: (1) routine developmental surveillance, such as the Social Responsiveness Scale (SRS) [91,92], the Social Communication Questionnaire (SCQ), and the Korean-Child Behavior Checklist (K-CBCL) as measures for emotional and behavioral problems (non-specific ASD); (2) specifically screen for ASD, such as the Autism Behavior Checklist (ABC), Quantitative Checklist for Autism in Toddlers (Q-CHAT), Modified Checklist for Autism in Toddlers (M-CHAT), and The Autism Treatment Evaluation Checklist (ATEC); and, (3) definitive diagnostic confirmation using the Childhood Autism Rating Scale (CARS), Autism Diagnostic Interview-Revised (ADI-R) and Autism Diagnostic Observation Schedule-Generic (ADOS-G). Of the above, only the ADI-R and ADOS-G (conducted jointly) have been seen as 'gold standard' diagnostic instruments that are appropriate for use in ASD 
research protocols. At the present time, however, neither tool has been standardised against the DSM 5, the forthcoming ICD 11 revision, or the NIH RDoC system.

Additionally, the assessment of the methodological quality of each eligible paper was performed in accordance with the methods section checklist of the Strengthening the Reporting of Observational Studies in Epidemiology (STROBE) statement [93]. Thus, to assess the evidence provided by the included papers based on STROBE, we considered the following features: (a) sample size and degree of homogeneity of the group studied; (b) use of a control group and the appropriateness of that selection; (c) type of observational design; (d) nature and degree of exposure to EDCs; (e) selection of assessment criteria-including the quality of the ASD diagnosis and the instruments or methods used (analyses in biological fluids, environmental reports and questionnaires/interviews); and, (f) adjustment for confounding factors, such as pharmacological treatments provided or environmental factors that could affect this association.

\subsection{Data Extraction}

The process of selecting the articles to be included in this review was carried out in two steps. First, two different groups (SMB, CDV, AMS \& MMSV, IPC, ALLG, SMR) from the research team independently assessed and screened the titles and abstracts of each potential study and collected descriptive information. Second, the studies that were selected in this first step were further examined by two members (SMB and MMSV) with expertise in epidemiology and the environmental health field. The resultant studies were compared to determine agreement for the search and inclusion criteria. The final overall quality and strength of the evidence was independently evaluated by each author. Finally, the evaluations were compared, the discrepancies discussed, and the final decisions were justified collectively.

\section{Results}

\subsection{Characteristics of Studies}

The search yielded 17 publications that met the inclusion criteria from a pool of 251 potential studies, and involved case-control and cohort study designs. The main differences among studies included were the sample size-from 30 to around 300,000 patients, age of children, and the measurement of the exposure to EDC. Regarding the data collection method of the studies, three (18\%) used questionnaires /interviews, (Table 4 ), eight (47\%) based on estimations provided by environmental government agencies (Table 5), and six (35\%) used analytical methods and biological samples (Table 6). The majority of the studies adjusted the assessments for several potential confounders, such as maternal age, parental level of education, race/ethnicity, gender of child, household income, tobacco smoke status, and some measure of socio-economic status. Due to the limited number of studies involved as well as their different methodologies we could not perform a meta-analysis. 
Table 4. Interview and questionnaires to parents.

\begin{tabular}{|c|c|c|c|c|c|}
\hline Author and Year & $\begin{array}{c}\text { Study Population and Sample } \\
\text { Size }(N)\end{array}$ & Study Design & Exposure & Outcome & Results \\
\hline Kim et al., 2010 & $\begin{array}{l}106 \text { mothers of children with } \\
\text { ADS and } 324 \text { mothers of } \\
\text { typically developing } \\
\text { (TD).children, and were } \\
\text { recruited from special and } \\
\text { elementary schools respectively } \\
\text { in Seoul, Chungju, and } \\
\text { Chuncheon, South Korea }\end{array}$ & Case-control study. & $\begin{array}{l}\text { Self-reported exposure. Two } \\
\text { questionnaires (knowledge/exposure) } \\
\text { asking about the potential risk to EDCs. } \\
\text { These questions regarding possible } \\
\text { exposure to PBDEs, PCBs, BPA and } \\
\text { PCDD were selected based on the } \\
\text { guidelines provided by the study } \\
\text { 'Ministry of Environment for the } \\
\text { Republic of Korea' }\end{array}$ & $\begin{array}{l}\text { The Child Behavior Checklist } \\
\text { Korean version (K-CBCL) was } \\
\text { used to assess the diagnosis } \\
\text { and severity of behavioral traits } \\
\text { of ASD in children }\end{array}$ & $\begin{array}{l}\text { The knowledge regarding the } \\
\text { possible toxicity to EDCs, such as } \\
\text { PBDEs, PCBs BPA, PCDD was } \\
\text { significantly higher in cases than } \\
\text { controls }(\mathrm{t}=2.9, p=0.001) \text { and } \\
\text { self-reported exposure was } \\
\text { significantly higher in cases than } \\
\text { controls }(\mathrm{t}=5.6, p=0.001)\end{array}$ \\
\hline Larsson et al., 2009 & $\begin{array}{l}72 \text { children ( } 60 \text { boys, } 12 \text { girls) } \\
\text { with ASD in the county of } \\
\text { Värmland, Sweden }\end{array}$ & $\begin{array}{l}\text { Retrospective study based } \\
\text { on the DBH longitudinal } \\
\text { cohort study }\end{array}$ & $\begin{array}{l}\text { Questionnaire asking for type of floor } \\
\text { material used at home (PVC, wood, } \\
\text { linoleum, etc.) as source of phthalates. }\end{array}$ & Parentally-reported ASD & $\begin{array}{l}\text { ASD aOR } 1.66 \text { (95\% CI: 1.02-2.7) for } \\
\text { children with PVC floor at home in } \\
\text { comparison with those with other } \\
\text { floor material. Poor ventilation was } \\
\text { also associated with ASD. }\end{array}$ \\
\hline McCanlies et al., 2012 & $\begin{array}{l}174 \text { families: } 93 \text { children with } \\
\text { ASD and } 81 \text { TD children born } \\
\text { and living in California, and } \\
\text { enrolled in the CHARGE study }\end{array}$ & Case-control study & $\begin{array}{l}\text { Industrial-Hygienist Evaluation } \\
\text { Exposures, i.e., occupational exposure } \\
\text { to asphalt and several solvents } \\
\text { including nickel, chromium, iron, } \\
\text { aluminum, lead, toluene, xylene, } \\
\text { phthalate, PCBs), and collected } \\
\text { retrospectively. }\end{array}$ & $\begin{array}{l}\text { ASD were assessed on the } \\
\text { Autism Diagnostic Interview } \\
\text { Revised (ADI-R) and the } \\
\text { Autism Diagnostic Observation } \\
\text { Schedules (ADOS) }\end{array}$ & $\begin{array}{l}\text { Higher exposure }(\mathrm{OR} \geq 2) \text { to } \\
\text { asphalt and solvents were observed } \\
\text { among parents with ASD children } \\
\text { compared with parents of TD } \\
\text { children. But no significant } \\
\text { associations after correcting }\end{array}$ \\
\hline
\end{tabular}

ASD: Autism Spectrum Disorder; TD: Tipically developing; ATEC: Autism Treatment Evaluation Checklist PBDEs: polybrominated diphenyl ethers; PCBs: polychlorinated biphenyls; BPA: bisphenol A; PCDD: polychlorinated dibenzo-p-dioxin; DBH: Dampness in buildings and Health; DSM-IV: Diagnostic and Statistical Manual of Mental Disorders, 4th edition; CHARGE: Childhood Autism Risks from Genetics and Environment study. 
Table 5. Estimation of concentrations of endocrine disruptors provided by environmental agencies.

\begin{tabular}{|c|c|c|c|c|c|}
\hline Author and Year & $\begin{array}{l}\text { Study Population and Sample Size } \\
(N)\end{array}$ & Study Design & Exposure & Outcome & Results \\
\hline Roberts et al., 2007 & $\begin{array}{l}\text { Cases: } 465 \text { children with ASD. } \\
\text { Controls: } 6975 \text { paired TD children } \\
\text { Central Valley } \\
\text { (California) }\end{array}$ & Case-control study. & $\begin{array}{l}\text { Residential proximity of sources of } \\
\text { agricultural pesticides: } \\
\text { organochlorines, organophosphates, } \\
\text { tTrifluralin) }\end{array}$ & $\begin{array}{l}\text { Children with ASD were } \\
\text { identified through electronic } \\
\text { files of the California } \\
\text { Department of Developmental } \\
\text { Services according the } \\
\text { Diagnostic and Statistical } \\
\text { Manual of Mental Disorders } \\
\text { (DSM IV-R) }\end{array}$ & $\begin{array}{l}\text { In children of mothers living within } 500 \mathrm{~m} \text { of field } \\
\text { sites (the fourth quartile vs. the lowest non-zero } \\
\text { quartile of organochlorine poundage to those } \\
\text { with mothers not living near field sites the aOR } \\
\text { was for ASD of } 6.1 \text { (95\% CI: 2.4-15.3). }\end{array}$ \\
\hline Roberts et al., 2013 & $\begin{array}{l}\text { Cases: } 325 \text { children with ASD } \\
(46 \text { girls, } 279 \text { boys). } \\
\text { Controls: } 22,101 \text { TD children. } \\
\text { From all } 50 \text { U.S. states. }\end{array}$ & $\begin{array}{l}\text { Case-control study from } \\
\text { the Nurses' Health Study } \\
\text { II cohort }\end{array}$ & $\begin{array}{l}\text { US EPA concentrations of several } \\
\text { pollutants according to residency: } \\
\text { Antimony, arsenic, cadmium, } \\
\text { chromium, lead, manganese, mercury, } \\
\text { nickel, all metals, diesel particulate, } \\
\text { styrene, and methylene chloride. }\end{array}$ & $\begin{array}{l}\text { ASD diagnosis validated by } \\
\text { telephone administration of the } \\
\text { Autism Diagnostic } \\
\text { Interview-Revised (ADI-R) to } \\
50 \text { randomly selected case } \\
\text { mothers }\end{array}$ & $\begin{array}{l}\text { Comparing the higher quintile score and the } \\
\text { lowest quintile } \\
\text { Lead: aOR }=1.6 ; 95 \% \text { CI: } 1.1,2.3 \\
\text { Manganese: } \mathrm{aOR}=1.5 ; 95 \% \text { CI: } 1.1,2.2 \\
\text { Mercury: aOR }=2 ; 95 \% \text { CI: } 1.2,3 . \\
\text { NickelL: aOR }=1.7 ; 95 \% \text { CI: } 1.1,2.5 \\
\text { Cadmium: aOR }=1.5 ; 95 \% \text { CI: } 1.0,2.1 \\
\text { Total metals: aOR }=1.5 ; 95 \% \text { CI: } 1.0,2.3 \\
\text { Styrene: aOR }=1.4 ; 95 \% \text { CI } 1.0,2.1 \\
\text { Methylenechloride: aOR } 1.8 ; 95 \% \text { CI: } 1.2,2.8 \\
\text { Diesel particulate: aOR }=2 ; 95 \% \text { CI: } 1.0,4.0\end{array}$ \\
\hline Shelton et al., 2014 & $\begin{array}{l}486 \text { cases (children with ASD) and } \\
316 \text { controls (TD children) } \\
\text { CHARGE study } \\
\text { California }\end{array}$ & Case-control study & $\begin{array}{l}\text { Proximity of homes to agricultural } \\
\text { pesticides is used to estimate pesticide } \\
\text { exposure using the Pesticide Use } \\
\text { Report (PUR). Pesticides included are } \\
\text { organophosphates, carbamates, } \\
\text { pyrethroids, organochlorates and } \\
\text { chlorpyrifos }\end{array}$ & $\begin{array}{l}\text { Children are administered the } \\
\text { Autism Diagnostic Observation } \\
\text { Schedule (ADOS), combined } \\
\text { with the ADI-R }\end{array}$ & $\begin{array}{l}\text { Residential proximity (within } 1.5 \mathrm{~km} \text { ) to } \\
\text { agricultural pesticides it was compared with } \\
\text { binary }(1=\text { exposed vs. } 0=\text { not exposed) indicators } \\
\text { during pregnancy and his association with ASD } \\
\text { Organophosphate pesticides: aOR }=2.07 \text {; }(95 \% \text { CI: } \\
\text { 1.23, } 3.50) \\
\text { Chlorpyrifos: aOR }=3.31 ;(95 \% \text { CI: } 1.48,7.42) \\
\text { Pyrethroids: aOR } 1.87 ;(95 \% \text { CI: } 1.02,3.43)\end{array}$ \\
\hline Talbott et al., 2015 & $\begin{array}{l}217 \text { cases (children with ASD) and } \\
\text { two different control groups: 1) } 224 \\
\text { matched TD children and 2) 5,007 } \\
\text { controls generated from a random } \\
\text { sample using birth certificates (BC). } \\
\text { Pennsylvania }\end{array}$ & $\begin{array}{l}\text { Case-control study } \\
\text { conducted by the } \\
\text { EPA-NATA }\end{array}$ & $\begin{array}{l}\text { Exposure to arsenic, chromium, } \\
\text { methylene chloride, styrene, lead, } \\
\text { cyanide, PAHs among other from } \\
\text { ambient air pollution concentrations } \\
\text { are estimated using modelled data } \\
\text { from the } 2005 \text { NATA data. }\end{array}$ & $\begin{array}{l}\text { ASD self-reported by family is } \\
\text { diagnosed according to specific } \\
\text { tests either such as ADOS or } \\
\text { the Social Communication } \\
\text { Questionnaire (SCQ) }\end{array}$ & $\begin{array}{l}\text { Comparing fourth to first quartile of exposures: } \\
\text { Styrene aOR } 1.61(95 \% \mathrm{CI}=1.08-2.38) \\
\text { Chromium aOR } 1.60(95 \% \mathrm{CI}=1.08-2.38) \\
\text { Methylene chloride aOR } 1.41 ; 95 \% \mathrm{CI}=0.96-2.07) \\
\text { PAHs aOR } 1.44 ; 95 \% \mathrm{CI}=0.98-2.11 \\
\text { Remaining compounds were not statistically } \\
\text { significant. }\end{array}$ \\
\hline Volk et al., 2011 & $\begin{array}{l}\text { Cases: } 304 \text { children with ASD. } \\
\text { Controls: } 259 \text { TD children. } \\
\text { California }\end{array}$ & $\begin{array}{l}\text { Case-control study based } \\
\text { on the CHARGE study. }\end{array}$ & $\begin{array}{l}\text { Residential proximity to a freeway } \\
\text { during pregnancy as a surrogate for air } \\
\text { pollution (traffic-related pollutants) }\end{array}$ & $\begin{array}{l}\text { The diagnosis of ASD was } \\
\text { evaluated from both the ADOS } \\
\text { and the ADI-R }\end{array}$ & $\begin{array}{l}\text { Residential proximity }(\leq 309 \mathrm{~m}) \text { was compared to } \\
\text { distance to the nearest freeway during the third } \\
\text { trimester of pregnancy and was associated with } \\
\text { ASD in offspring (aOR }=2.22 ; 95 \% \text { CI: } 1.16-4.42) \text {. } \\
\text { No association with living close to other main } \\
\text { roads during pregnancy and ASD. }\end{array}$ \\
\hline
\end{tabular}


Table 5. Cont

\begin{tabular}{|c|c|c|c|c|c|}
\hline Author and Year & $\begin{array}{l}\text { Study Population and Sample Size } \\
(N)\end{array}$ & Study Design & Exposure & Outcome & Results \\
\hline von Ehrenstein et al., 2014 & $\begin{array}{l}\text { Cohort of children }(n=148,722) \text { of } \\
\text { which } 768 \text { were diagnosed with ASD. } \\
\text { Los Angeles County, California }\end{array}$ & $\begin{array}{l}\text { Observational cohort } \\
\text { study }\end{array}$ & $\begin{array}{l}\text { 1,3-butadiene, lead, benzene, toluene, } \\
\text { ethyl-benzene, xylenes, formaldehyde, } \\
\text { and chlorinated solvents measured by } \\
\text { community-based air-monitoring } \\
\text { stationsin mothers residing at } 5 \mathrm{~km} \\
\text { from air-toxics during pregnancy. }\end{array}$ & $\begin{array}{l}\text { ASD cases are identified } \\
\text { through records maintained by } \\
\text { the California Department of } \\
\text { Developmental Services and } \\
\text { diagnosed according the DSM } \\
\text { IV-R }\end{array}$ & $\begin{array}{l}\text { ASD increased risk per interquartile-range } \\
\text { increase of exposures: } \\
\text { 1,3-butadiene: } \mathrm{aOR}=1.59 ; 95 \% \text { CI: } 1.18-2.15 \\
\text { Meta / para-xylene: } \mathrm{aOR}=1.51 ; 95 \% \text { CI: } 1.26-1.82 \\
\text { Lead: aOR }=1.49 ; 95 \% \mathrm{CI}=1.23-1.81 \\
\text { Perchloroethylene: } \mathrm{aOR}=1.40 ; 95 \% \text { CI: } 1.09-1.80 \\
\text { Formaldehyde: aOR }=1.34 ; 95 \% \text { CI: } 1.17-1.52\end{array}$ \\
\hline Windham et al., 2006 & $\begin{array}{l}\text { Cases: } 284 \text { children with ASD. } \\
\text { Controls: } 657 \text { TD children. } \\
\text { Born in } 1994 \text { and live in San } \\
\text { Francisco. } \\
\text { California }\end{array}$ & Case-control study & $\begin{array}{l}\text { Exposure to } 25 \text { environmental } \\
\text { pollutants is estimated by the US EPA } \\
\text { according to place of residence. }\end{array}$ & $\begin{array}{l}\text { The diagnosis of ASD is made } \\
\text { by qualified medical } \\
\text { professionals according to the } \\
\text { criteria of DSM-IV }\end{array}$ & $\begin{array}{l}\text { ASD risk in the upper quartiles of chemical } \\
\text { concentrations compared with those below the } \\
\text { median. } \\
\text { Chlorinated solvents: } \\
\text { Methylene chloride: aOR }=1.50 ; 95 \% \text { CI: } 1.06,2.13 \\
\text { Trichloroethylene: aOR }=1.47 ; 95 \% \text { CI: } 1.03,2.08 \\
\text { Vinyl chloride: aOR }=1.75 ; 95 \% \text { CI: } 1.25,2.43 \\
\text { Metals: } \\
\text { Cadmium: aOR } 1.54 ; 95 \% \text { CI: } 1.08,2.20 \\
\text { Mercury: aOR } 1.92 ; 95 \% \text { CI: } 1.36,2.71 \\
\text { Nickel: aOR } 1.46 ; 95 \% \text { CI: } 1.04,2.06 \\
\text { Other exposures were not associated with ASD }\end{array}$ \\
\hline Windham et al., 2013 & $\begin{array}{l}\text { Parental occupation was obtained } \\
\text { from birth certificates for } 284 \\
\text { children with autism and } 659 \\
\text { controls, born in } 1994 \text { in the San } \\
\text { Francisco Bay Area (California) }\end{array}$ & Case-control study & $\begin{array}{l}\text { Self-reported occupation and industry } \\
\text { exposures are coded into eight } \\
\text { chemical groups (exhaust/combustion } \\
\text { products, disinfectants, metals, } \\
\text { pesticides, solvents, cooling fluids, and } \\
\text { auto paint) }\end{array}$ & $\begin{array}{l}\text { Autism cases are identified } \\
\text { according the DSM-IV by } \\
\text { qualified medical professionals }\end{array}$ & $\begin{array}{l}\text { Mothers of children with ASD had a higher } \\
\text { probability (aOR }=2.3 ; 95 \% \text { CI: } 1.3,4.2 \text { ) of working } \\
\text { in occupations considered exposed compared to } \\
\text { mothers of controls (non-exposed). } \\
\text { The exposure categories of the greatest frequency } \\
\text { among case mothers were exhaust and } \\
\text { combustion products (aOR 12.0; } 95 \% \text { CI: } 1.4,104.6 \text { ) } \\
\text { and disinfectants (aOR } 4.0 ; 95 \% \text { CI: 1.4, 12.0). }\end{array}$ \\
\hline
\end{tabular}

TD: typically develop; EPA-NATA: US Environmental Protection Agency National-Scale Air Toxics Assessment; ADOS: Autism Diagnostic Observation Schedule; ADI-R: Autism

Diagnostic Interview, Revised. 
Table 6. Analysis of the concentrations of endocrine disruptors in biological samples.

\begin{tabular}{|c|c|c|c|c|c|}
\hline Author and Year & $\begin{array}{l}\text { Study Population and Sample Size } \\
(N)\end{array}$ & Study Design & Exposure & Outcome & Results \\
\hline Braun et al., 2014 & $\begin{array}{l}175 \text { pregnant women } \geq 18 \text { year from } \\
\text { Cincinnati. }\end{array}$ & $\begin{array}{l}\text { Observational study with } \\
\text { the prospective birth } \\
\text { cohort HOME }\end{array}$ & $\begin{array}{l}8 \text { phthalate metabolites, BPA, } 25 \text { PCBs, } \\
6 \text { organochlorine pesticides, } 8 \\
\text { brominated flame retardants and } 4 \\
\text { PFAS in maternal serum or urine } \\
\text { samples taken at gestation weeks } \\
\text { 16-26. }\end{array}$ & $\begin{array}{l}\text { Mothers completed the SRS } \\
\text { questionnaire when children } \\
\text { were } 4-5 \text { years old to evaluate } \\
\text { autistic behavior }\end{array}$ & $\begin{array}{l}\text { Trans-nonachlor and PBDE-28 were associated } \\
\text { with autistic behaviors, } \beta=4.1 ; 95 \% \text { CI: } 0.8-7.3 \\
\text { and } \beta=2.5 ; 95 \% \text { CI: } 0.6-5.6 \text {, respectively. } \\
\text { Weak associations (not reaching the statistically } \\
\text { significance) were observed for PCB- } 178 \\
(\beta=-3.0 ; 95 \% \text { CI: }-6.3,0.2), \beta-\mathrm{HCH}(\beta=-3.3 \text {; } \\
\text { 95\% CI: }-6.1,-0.5), \text { PBDE- } 85(\beta=-3.2 ; 95 \% \text { CI } \\
-5.9,-0.5) \text { and PFOA ( } \beta=-2.0 ; 95 \% \\
\text { CI: }-4.4,0.4) \text {. }\end{array}$ \\
\hline Cheslack-Postava et al., 2013 & $\begin{array}{l}\text { Cases: } 75 \text { children with ASD. } \\
\text { Controls: } 75 \text { TD children. } \\
\text { Finland }\end{array}$ & $\begin{array}{l}\text { Nested case-control pilot } \\
\text { study in the Finnish } \\
\text { Maternity Cohort }\end{array}$ & $\begin{array}{l}\text { It is measured different } \mathrm{PCB} \text { congeners, } \\
\text { PBDE, } \mathrm{HCB}, \mathrm{DDT} \text {, and its metabolite } \\
\text { (DDE) in maternal serum samples } \\
\text { taken during pregnancy. }\end{array}$ & $\begin{array}{l}\text { ASD in children validated by } \\
\text { the ADI- } R \text {. }\end{array}$ & $\begin{array}{l}\text { No significant association with ASD was found } \\
\text { for any compound. } \\
\text { The aOR of ASD in the >90th of exposure was } \\
\text { compared to the lower end of the control } \\
\text { distributions: } \\
\text { PCBs aOR } 1.91 \text { ( } 95 \% \text { CI: } 0.57,6.39) \\
\text { HCB aOR } 0.89 \text { ( } 95 \% \text { CI } 0.28,2.76) \\
\text { DDE aOR } 1.79 \text { ( } 95 \% \text { CI: } 0.51,6.21 \text { ) }\end{array}$ \\
\hline Liew et al., 2015 & $\begin{array}{l}220 \text { cases (children with ASD), and } \\
550 \text { TD children (controls) are } \\
\text { selected from the Danish National } \\
\text { Birth Cohort, Denmark }\end{array}$ & Nested case-control study. & $\begin{array}{l}\text { Six PFASs measured in maternal } \\
\text { plasma collected in early or } \\
\text { mid-pregnancy }\end{array}$ & $\begin{array}{l}\text { All diagnoses are based on } \\
\text { ICD-10, code F84.0 }\end{array}$ & $\begin{array}{l}\text { No associations were observed for any of the } \\
\text { PFAS assessed in relation to ASD. }\end{array}$ \\
\hline Lyall et al., 2017 & $\begin{array}{l}\text { Cases: } 545 \text { children with ASD } \\
\text { Controls: } 418 \text { TD children. } \\
\text { California }\end{array}$ & $\begin{array}{l}\text { Population-based } \\
\text { case-control study }\end{array}$ & $\begin{array}{l}\text { Concentrations of } 11 \mathrm{PCB} \text { congeners } \\
\text { and } 2 \text { OCPs measured in banked } \\
\text { second-trimester serum samples and } \\
\text { was compared between both groups }\end{array}$ & $\begin{array}{l}\text { The diagnosis of ASD based on } \\
\text { DSM-IV-TR criteria }\end{array}$ & $\begin{array}{l}\text { OCPs were no associated with ASD and only } 2 \\
\text { PCB congeners showed significant association. } \\
\text { Comparing highest with the first quartile of } \\
\text { PCBs: the OR of ASD were PCB138 /158: } \\
\text { aOR }=1.79 \text { ( } 95 \% \text { CI: } 1.10,2.92) \text { and PCB153: } \\
\text { aOR }=1.82 \text { ( } 95 \% \text { CI: } 1.10,3.02) \text {. }\end{array}$ \\
\hline Miodovnik et al., 2011 & $\begin{array}{l}137 \text { mothers and their children born } \\
\text { at Hospital Mount Sinai. } \\
\text { New York City }\end{array}$ & $\begin{array}{l}\text { Observational prospective } \\
\text { cohort study. }\end{array}$ & $\begin{array}{l}\text { Concentration of } 10 \text { metabolites of } \\
\text { phthalates and BPA of maternal urine } \\
\text { samples taken during the third } \\
\text { trimester of pregnancy. }\end{array}$ & $\begin{array}{l}\text { Mothers completed the SRS for } \\
\text { detecting and measuring the } \\
\text { severity of autistic behavior. }\end{array}$ & $\begin{array}{l}\Sigma \text { LMWP } \beta 1.53 ; 95 \% \text { CI: } 0.25-2.8 \\
\text { MEP } \beta=1.38 ; 95 \% \text { CI: } 0.23,2.53\end{array}$ \\
\hline Nowack et al., 2015 & $\begin{array}{l}\text { Out of } 133 \text { invited parents, } 100 \text { filled } \\
\text { out the questionnaire SRS ( } N=100) \\
\text { Duisburg, (Germany) }\end{array}$ & $\begin{array}{l}\text { Observational cohort } \\
\text { study }\end{array}$ & $\begin{array}{l}\text { Concentrations of PCDD/Fs and PCBs } \\
\text { measured in maternal whole blood } \\
\text { samples during pregnancy. }\end{array}$ & $\begin{array}{l}\text { Diagnosis and measurement of } \\
\text { autistic behavior by the SRS. }\end{array}$ & $\begin{array}{l}\text { Overall PCDD/Fs and PCBs were negatively } \\
\text { associated with autistic behavior, PCDD/Fs: } \\
\beta=-6.66(95 \% \text { CI: }-11.88,1.44 . p<0.05) ; \\
\text { PCB: } \beta=-3.99(95 \% \text { CI: }-8.61,0.64 . p=0.09) \text {. }\end{array}$ \\
\hline
\end{tabular}




\subsection{Internal Validity for Individual Studies}

We evaluated the internal validity (risk of systematic bias) in each study. Several studies presented validity problems, such as the no specification of inclusion criteria, the small sample size, the lack of a control group, as well as the failure to take into account phenotypic variability between individuals or to explore alternative explanations. In addition, errors in the data that were provided through questionnaires/interviews answered by parents with insufficient training or values being deliberately biased are likely. The studies that were ultimately rated as having "high" or "probably high" risk of exposure assessment bias used data from questionnaires/interviews, or estimated the exposure from the national and public data, such as the Toxic Release Inventory (TRI) or the US EPA National-scale Air Toxics Assessment (NATA). Likewise, well-known potential confounding variables were not taken into account in some of the studies. However, in the majority of domains other than those referring to exposure assessment and confounding factors, most studies were rated as "low" or "probably low" risk of bias (Figure 2).

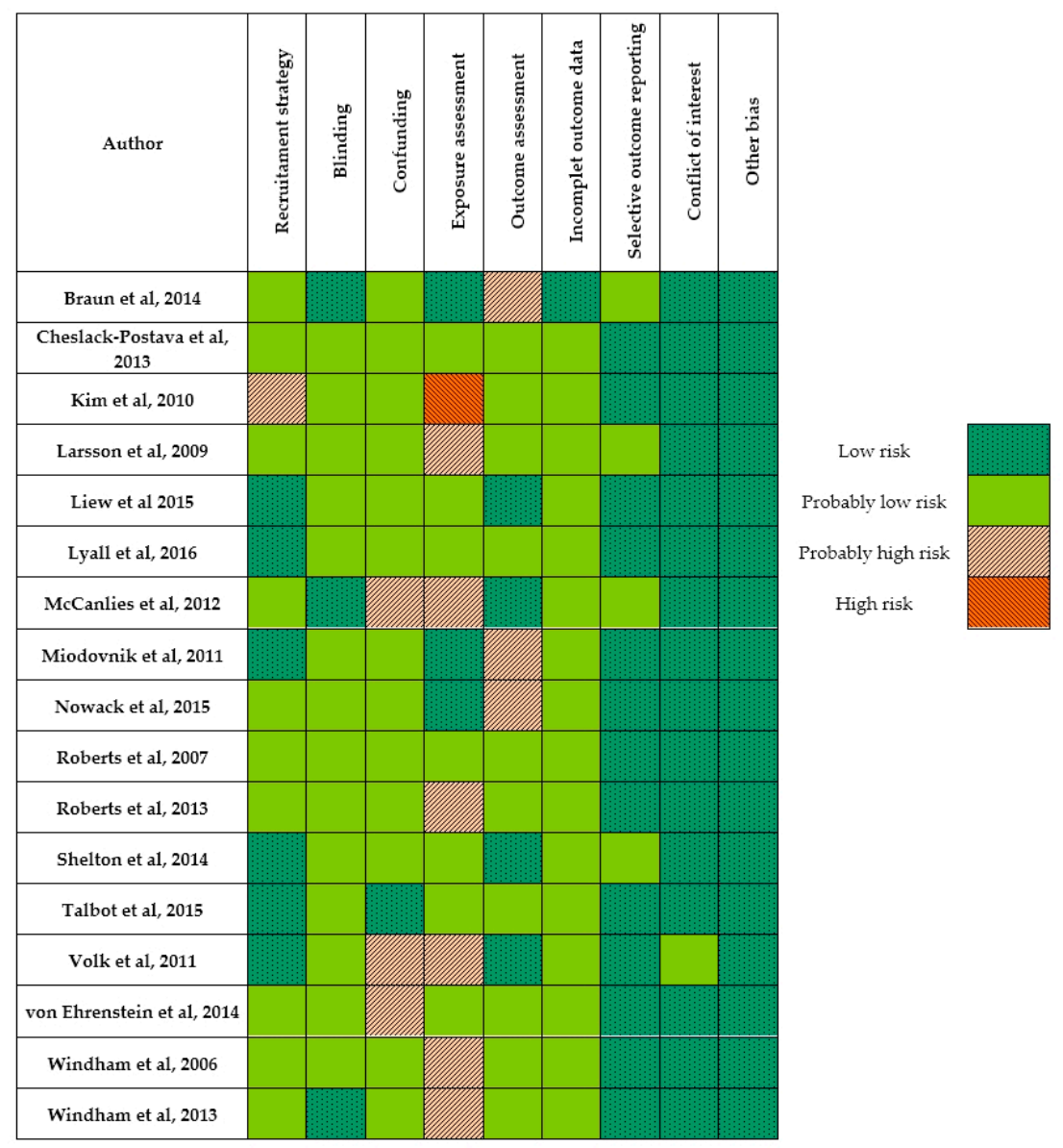

Figure 2. Summary of risk of bias assessment across individual studies. Review of authors' judgments (low, probably low, probably high, and high risk) of bias for each risk of bias domain for each included study $(n=17)$.

\subsection{Risk of Bias Exposure Assessment for Individual Studies}

The exposure assessment risk of bias in those studies using interviews/questionnaires was "high" in Kim et al., (2010) (PBDEs, PCBs, BPA, and PCDD); and, "probably high" in Larsson et al., (2009) [94] (phtalates) and McCanlies et al., (2012) [95] (asphalt and solvents).

Among studies using NATA data, Robert et al., 2013 [96] (mercury, lead, nickel, methylene chloride, and diesel), Volk et al., 2011 [27] (traffic-related air pollution near a freeway), Windham 
et al., 2006 [97] (chlorinated solvents and heavy metals), and Windham et al., 2013 [98] (exhaust and combustion products and disinfectants) were assigned as "probably high" risk of exposure assessment bias. Likewise, Roberts et al., 2007 [99] (organochlorine pesticides), Shelton et al., 2014 [100] (organophosphorus pesticides [cholpyrifos], heavy metals, pyrethroids, styrene, and PHA), Talbott et al., 2015 [101] (styrene), and von Ehrenstein et al., 2014 [102] (1,3-butadiene, lead, benzene, toluene, ethyl-benzene, xylenes, formaldehyde, and chlorinated solvents) were ranked as "probably low" risk of exposure assessment bias.

Among studies based on laboratory analysis, Braun et al., 2014 [19] (phthalate metabolites, BPA, PCBs, organochlorine pesticides, brominated flame-retardants, and PFAS), Miodovnik et al., 2011 [103] (metabolites of the phthalates, and BPA), and Nowack et al., 2015 [104] (PCDD/Fs and PCBs) were classified as "low" risk of bias. Equally, Cheslack-Postava et al., 2013 [105] (PCBs, HCB, DDE, and PFAS) and Liew et al., 2015 [106] (PCBs and OCPs) were assigned as "probably low".

\subsection{Summary of Results}

In general, we observed a trend towards positive effects (exposure to overall EDCs was associated with an increased risk of ASD). One of the primary reasons for rating up the quality of evidence is when a large enough magnitude of effect exists [107]. According to the GRADE working group [107] guidelines, the magnitude of effect that may increase the quality of evidence are as follows: large magnitude of effect (direct evidence, relative risk $[R R]$, or odds ratio $[O R]=2-5$ or $R R / O R=0.5-0.2$ with no plausible confounders); very large magnitude of effect (RR/OR $>5$ or RR/OR $<0.2$ and no serious problems with risk of bias or precision with sufficiently narrow confidence intervals). The groups of EDC that reported consistently significant OR/RR of ASD > 2 were: "industrial chemical contaminants" (e.g., lacquers, asphalt, styrene and xylene), "exhaustion and combustion products", "agricultural pesticides" (e.g., pyrethroids, organochlorines, and organophosphates), and "plastics" (bisphenol A). Those EDCs that reported OR/RR < 2 included "heavy metals" (cadmium, chromium, lead, nickel, and mercury) and "phthalates". PFAS and DDT metabolites did not reach the statistical significance. However, there was a considerable risk of systematic bias due to the exposure assessment-with several studies rated as "high" or "probably high"—for many of these EDCs.

\subsection{Quality of the Overall Body of Evidence}

Based on our evaluation using the Navigation Guide criteria, we rated the initial quality of evidence across overall EDCs as "moderate". The decisions leading to this rating are based primarily on the concern that many of the studies showed "high" or "probably high" exposure assessment risk of bias, mainly because of the exposure assessment methodology, which included: extrapolation of data from the amount of emissions to individual or community exposures, measuring exposure using varied metrics (i.e., environmental monitoring, emissions-based modeling, or occupation/work place as exposure estimation). Nevertheless, because of several EDCs shown OR or RR of ASD greater than 2, we did not need to degrade or upgrade the evidence, and therefore the initial "moderate" rating was retained.

\subsection{Strength of the Overall Body of Evidence}

Prenatal exposure to EDCs was associated with an increased risk of ASD development. However, this relationship is constrained, and then cannot be ruled out with reasonable confidence by such factors as: quality of the overall body of evidence, the direction of the effect, confidence in the effect, the number, or size of studies included. Based on the consistency of the findings across the studies, we concluded that the final overall strength of the evidence on a positive association between prenatal EDC exposure and offspring ASD development is "limited" (Table 7). 
Table 7. Quality and strength of evidence (Woodruff et al., 2011).

\begin{tabular}{|c|c|c|}
\hline Factor & & Explanation \\
\hline \multicolumn{3}{|c|}{ Downgrades } \\
\hline Risk of bias & 0 to -1 & $\begin{array}{l}\text { Based on the high/probably high risk of bias across the studies, mostly driven by the } \\
\text { exposure assessment methods and the outcome evaluation (DSM, ICD-10, SRS, } \\
\text { ADOS, ADI-R). The lack of specificity across different types of EDCs was of special } \\
\text { concern. }\end{array}$ \\
\hline Indirectness & 0 to -1 & $\begin{array}{l}\text { Based on the adequate assessment of the exposure at individual level. There is a lack } \\
\text { of individual EDC (or metabolites) and/or the exposures are not directly measured; } \\
\text { for instance, Larsson et al. (2009) uses the floor material, McConlies et al. (2012) the } \\
\text { occupational exposure and Volk et al. (2011) the residential proximity as a indicators } \\
\text { of EDC. }\end{array}$ \\
\hline Inconsistency & 0 & $\begin{array}{l}\text { With few exceptions [Liew et al. (2015), Cheslack-Postava et al. (2013), and Mc } \\
\text { Canlies et al. (2012)] results across studies are generally consistent in the magnitude } \\
\text { and direction. Although most of the studies showed positive EDC-ASD associations, } \\
\text { the magnitude of the effect was small and the statistical significance was not reached } \\
\text { in many of them. }\end{array}$ \\
\hline \multicolumn{3}{|c|}{ Upgrades } \\
\hline Magnitude of effect & 0 to +1 & $\begin{array}{l}\text { Most of the studies found slight effects (i.e., OR }<2) \text {. However, several studies } \\
\text { showed greater evidence of risk of ASD }(\text { RR or OR }>2)\end{array}$ \\
\hline Dose-response & 0 & $\begin{array}{l}\text { The authors considered that there was some evidence of a dose-response } \\
\text { relationship. }\end{array}$ \\
\hline Confounding & 0 & $\begin{array}{l}\text { We did not find evidence that possible residual confounding influenced results. } \\
\text { In the studies retrieved potential confounders and effect modifiers they were } \\
\text { examined including population characteristics such as race and ethnicity } \\
\text { distribution, whether the tract was urban or rural, level of education, age of } \\
\text { participants, percentage of the population below the poverty line, and median } \\
\text { household income, among other. }\end{array}$ \\
\hline
\end{tabular}

\section{Discussion}

We applied the Navigation Guide systematic review method to summarize the evidence of the association between prenatal EDCs exposure and later ASD development in children. To date, the Navigation Guide method has been used in few studies [108-113]. We believe however, that this methodology guarantees greater confidence, since it is a systematic, robust, and rigorous approach to research synthesis in the evaluation of evidence-based medicine and environmental health. Likewise, it is based in a pre-defined question and protocol, standardized and transparent documentation, including a comprehensive search strategy as well as more accurate assessment of "risk of bias" for individual studies.

This systematic review aimed to evaluate the quality individually in each of the studies assessing the potential higher odds of a future ASD of those children whose mother were exposed to EDC during pregnancy and summarize the existing evidence to date. In general, the studies found that those mothers with children that were diagnosed with ASD were more exposed to EDC during pregnancy. However, we found that the quality and strength of these studies were "moderate" and "limited", respectively.

\subsection{Limitations of the Review Process}

This review process has some limitations. First, the review itself may be sensitive to publication bias and we might not have retrieved all of the relevant publications on the subject (e.g., studies that could have had repercussion in the conclusion of this review). To take into account the different methodologies used to measure the EDCs, we grouped the studies based on the method of the 
exposure assessment used. However, the wide variety of different EDCs addressed, the different times of exposure (first, second, or third trimester of pregnancy), as well as the differences in the methodology of the ASD across the studies are other limitations of this review. Although the variability in the diagnostic criteria among studies is representative of the time in which the study was conducted, it could affect the estimations. This suggests the need for a unified and globally accepted diagnostic criterion, i.e., the DSM-5.

In order to faithfully apply all of the steps recommended in the methodology of the Navigation Guide, human and non-human evidence should be integrated. This is, however, a preliminary study of a larger project that will also include a systematic review of the current experimental and animal evidence of the suggested relationship between the EDCs and autistic behavioral outcomes.

\subsection{Overview of the Topic, Recommendations and Implications}

The methodological limitations identified on retrieved studies were associated with a range of factors: the lack of a control group and/or clear definitions of inclusion criteria, very small sample sizes, groups being heterogeneous in terms of age or failure to control for phenotypic variability between individuals. There was also a risk of bias due to behavioral variables that were attributable to the memory of parents and other caregivers being distorted over time, or lack of adjustment for potential confounding variables (maternal age, maternal race, maternal education level, maternal BMI (body mass index), maternal smoking, maternal social status, family income, infant sex, gestational age, alcohol consumption, country of birth, delivery type, or birth weight, among others).

On the other hand, there are several reasons for which the evidence obtained from the studies included in this review may not be classified as "sufficient": the time lapse between chemical exposure and ASD diagnosis; the difficulty of calculating real exposure levels; and, the lack of information on the effects of combined exposures, among others.

\subsection{Biological Plausibility}

Animal experiments allow us to assess the biologic plausibility of the associations that were observed in epidemiologic studies (e.g., the relationship between exposure to EDCs and ASD) and mechanisms of action have been inferred from animal and in vitro models. Animal studies have shown that these exposures generally result in decreased T4 levels and/or increased TSH levels. In rats, a relationship between PBDE exposure and learning and memory alteration has been observed and the chronic exposure of parent zebrafish to low doses of PBDE led to neurobehavioral changes in their offspring [114]. Gestational exposure to CPF (chlorpyrifos) in rats impairs neuronal differentiation, synaptogenesis, and gene expression, and it affects the cholinergic, serotoninergic, and dopaminergic neurotransmitters, in a sex-dimorphic fashion [115].

EDCs and their metabolites can interact with the endocrine molecular signaling system as ligands (agonist or antagonist or co-activator) of transcription factors, disrupting the normal neuro-physiological mechanisms [116].

For instance, thyroid hormones play a critical role in neurodevelopmental processes, such as neuronal growth, cell migration, synaptogenesis, and myelination. The foetus cannot produce Thyroid-stimulating hormone (TSH) before the second trimester of pregnancy and it is entirely dependent on maternal thyroid hormone. TSH regulates the synthesis and secretion of thyroid hormones, which in turn are involved in neurodevelopment. TSH levels can be moderated by the hypothalamus through the release of the thyrotropin releasing hormone (TRH) and interactions between the hypothalamus-pituitary-thyroid/gonadal axis can be inhibited or stimulated by exposure to chemical pollutants [71,72].

ASD is approximately four times more prevalent in males than in females. This difference indicates that sex hormones likely also play a role in the disorder [66]. The authors of the "extreme male brain theory" of autism observed elevated fetal steroid hormones (including testosterone, estradiol, progesterone, androstenedione, and cortisol, among others), linked to ASD in their children [67]. 
Prenatal exposures to EDCs may induce a variety of autistic features (ASD applies to a very heterogeneous group of people with different levels of ability and severity), through changes in gene expression, leading to altered hormonal signaling pathways [68,115]. For instance, DNA methylation [117], histone modifications [118], and altered microRNA expression [119,120] produce alterations in the metabolome, which affects neural pathways linked to behaviors that are associated with ASD. EDC-induced phenotypic changes have been linked to ASD-specific epigenetic changes $[121,122]$.

\section{Conclusions}

This description of studies published to date aims to serve as a summary of the current available scientific evidence. The current limited epidemiological studies, the weak associations of the retrieved studies, and incomplete understanding of biological mechanisms precludes the establishment of a causal relationship. However, the ubiquitous presence of EDCs, their persistence and bioaccumulation, and the biologically plausibility highlight the need to carry out well-designed studies on the associations between EDC exposure during pregnancy and ASD during childhood. Future studies should overcome the limitations present in the studies conducted so far, and, for instance, be developed in larger datasets quantifying exposures using biomarkers and with validated instruments. Likewise, identify critical windows of vulnerability not only during embryo and fetal development, but also during infancy, early childhood, and adolescence is also required. Also, given the evidence that does exists, it is important to be aware of this risk that exposure to EDCs may pose and minimize its impact as much as possible. Prevention and early intervention should become the goal for all professionals involved, from environmental scientist to health professionals, such as obstetricians, gynecologists, midwives, pediatricians, GPs, neurologist, psychiatrist, psychologist, and occupational health professionals given the vulnerability of those involved and the possible long term effects of exposure.

Author Contributions: M.M.-S.-V. and S.M.-B. conceived the review. M.M.-S.-V., S.M.-B., and C.D.-V. performed literature search, collected the data, wrote the first draft and edited subsequent drafts. A.L.-G., A.M.-S., I.P.-C., J.L.-M. and S.M.-B. reviewed the data collected and contributed significantly to editing the manuscript. All authors approved the final version of the manuscript.

Funding: This research received no external funding.

Conflicts of Interest: The authors declare no conflict of interest.

\section{References}

1. Kohane, I.S.; McMurry, A.; Weber, G.; MacFadden, D.; Rappaport, L.; Kunkel, L.; Bickel, J.; Wattanasin, N.; Spence, S.; Murphy, S.; et al. The Co-Morbidity Burden of Children and Young Adults with Autism Spectrum Disorders. PLoS ONE 2012, 7, e33224. [CrossRef] [PubMed]

2. Lai, M.-C.; Lombardo, M.V.; Baron-Cohen, S. Autism. Lancet 2014, 383, 896-910. [CrossRef]

3. Matson, J.L.; Kozlowski, A.M. The increasing prevalence of autism spectrum disorders. Res. Autism Spectr. Disord. 2011, 5, 418-425. [CrossRef]

4. Baxter, A.J.; Brugha, T.S.; Erskine, H.E.; Scheurer, R.W.; Vos, T.; Scott, J.G. The epidemiology and global burden of autism spectrum disorders. Psychol. Med. 2014, 45, 601-613. [CrossRef] [PubMed]

5. Elsabbagh, M.; Divan, G.; Koh, Y.-J.; Kim, Y.S.; Kauchali, S.; Marcín, C.; Montiel-Nava, C.; Patel, V.; Paula, C.S.; Wang, C.; et al. Global Prevalence of Autism and Other Pervasive Developmental Disorders. Autism Res. 2012, 5, 160-179. [CrossRef] [PubMed]

6. Centers for Disease Control and Prevention. Prevalence of Autism Spectrum Disorder Among Children Aged 8 Years-Autism and Developmental Disabilities Monitoring Network, 11 Sites, United States, 2014. MMWR Surveill. Summ. 2018, 67, 1-23. [CrossRef] [PubMed] 
7. Christensen, D.L.; Baio, J.; Braun, K.V.N.; Bilder, D.; Charles, J.; Constantino, J.N.; Daniels, J.; Durkin, M.S.; Fitzgerald, R.T.; Kurzius-Spencer, M.; et al. Prevalence and Characteristics of Autism Spectrum Disorder Among Children Aged 8 Years-Autism and Developmental Disabilities Monitoring Network, 11 Sites, United States, 2012. MMWR Surveill. Summ. 2016, 65, 1-23. [CrossRef] [PubMed]

8. Christensen, D.L.; Bilder, D.A.; Zahorodny, W.; Pettygrove, S.; Durkin, M.S.; Fitzgerald, R.T.; Rice, C.; Kurzius-Spencer, M.; Baio, J.; Yeargin-Allsopp, M. Prevalence and characteristics of autism spectrum disorder among 4-year-old children in the autism and developmental disabilities monitoring network. J. Dev. Behav. Pediatr. 2016, 37, 1-8. [CrossRef] [PubMed]

9. Newschaffer, C.J.; Croen, L.A.; Daniels, J.; Giarelli, E.; Grether, J.K.; Levy, S.E.; Mandell, D.S.; Miller, L.A.; Pinto-Martin, J.; Reaven, J.; et al. The Epidemiology of Autism Spectrum Disorders. Annu. Rev. Public Health 2007, 28, 235-258. [CrossRef] [PubMed]

10. Geschwind, D.H. Autism: Many Genes, Common Pathways? Cell 2008, 135, 391-395. [CrossRef] [PubMed]

11. Bailey, A.; Le Couteur, A.; Gottesman, I.; Bolton, P.; Simonoff, E.; Yuzda, E.; Rutter, M. Autism as a strongly genetic disorder: Evidence from a British twin study. Psychol. Med. 1995, 25, 63. [CrossRef] [PubMed]

12. Steffenburg, S.; Gillberg, C.; Hellgren, L.; Andersson, L.; Gillberg, I.C.; Jakobsson, G.; Bohman, M. A Twin Study of Autism in Denmark, Finland, Iceland, Norway and Sweden. J. Child Psychol. Psychiatry 1989, 30, 405-416. [CrossRef] [PubMed]

13. Hallmayer, J. Genetic Heritability and Shared Environmental Factors Among Twin Pairs with Autism. Arch. Gen. Psychiatry 2011, 68, 1095. [CrossRef] [PubMed]

14. Tordjman, S.; Somogyi, E.; Coulon, N.; Kermarrec, S.; Cohen, D.; Bronsard, G.; Bonnot, O.; Weismann-Arcache, C.; Botbol, M.; Lauth, B.; et al. Gene $\times$ Environment Interactions in Autism Spectrum Disorders: Role of Epigenetic Mechanisms. Front. Psychiatry 2014, 5. [CrossRef] [PubMed]

15. Hu, V.W. From Genes to Environment: Using Integrative Genomics to Build a "Systems-Level" Understanding of Autism Spectrum Disorders. Child Dev. 2012, 84, 89-103. [CrossRef] [PubMed]

16. LaSalle, J.M. Epigenomic strategies at the interface of genetic and environmental risk factors for autism. J. Hum. Genet. 2013, 58, 396-401. [CrossRef] [PubMed]

17. Ronald, A.; Pennell, C.E.; Whitehouse, A.J.O. Prenatal Maternal Stress Associated with ADHD and Autistic Traits in early Childhood. Front. Psychol. 2011, 1. [CrossRef] [PubMed]

18. Roth, T.L. Epigenetics of neurobiology and behavior during development and adulthood. Dev. Psychobiol. 2012, 54, 590-597. [CrossRef] [PubMed]

19. Braun, J.M.; Kalkbrenner, A.E.; Just, A.C.; Yolton, K.; Calafat, A.M.; Sjödin, A.; Hauser, R.; Webster, G.M.; Chen, A.; Lanphear, B.P. Gestational Exposure to Endocrine-Disrupting Chemicals and Reciprocal Social, Repetitive, and Stereotypic Behaviors in 4- and 5-Year-Old Children: The HOME Study. Environ. Health Perspect. 2014, 122, 513-520. [CrossRef] [PubMed]

20. De Cock, M.; Maas, Y.G.H.; van de Bor, M. Does perinatal exposure to endocrine disruptors induce autism spectrum and attention deficit hyperactivity disorders? Review. Acta Paediatr. 2012, 101, 811-818. [CrossRef] [PubMed]

21. Kajta, M.; Wójtowicz, A.K. Impact of endocrine-disrupting chemicals on neural development and the onset of neurological disorders. Pharmacol. Rep. 2013, 65, 1632-1639. [CrossRef]

22. Kim, S.M.; Han, D.H.; Lyoo, H.S.; Min, K.J.; Kim, K.H.; Renshaw, P. Exposure to Environmental Toxins in Mothers of Children with Autism Spectrum Disorder. Psychiatry Investig. 2010, 7, 122. [CrossRef] [PubMed]

23. Lanphear, B.P. The Impact of Toxins on the Developing Brain. Annu. Rev. Public Health 2015, 36, $211-230$. [CrossRef] [PubMed]

24. Lyall, K.; Schmidt, R.J.; Hertz-Picciotto, I. Maternal lifestyle and environmental risk factors for autism spectrum disorders. Int. J. Epidemiol. 2014, 43, 443-464. [CrossRef] [PubMed]

25. Sandin, S.; Lichtenstein, P.; Kuja-Halkola, R.; Larsson, H.; Hultman, C.M.; Reichenberg, A. The Familial Risk of Autism. JAMA 2014, 311, 1770. [CrossRef] [PubMed]

26. Shelton, J.F.; Hertz-Picciotto, I.; Pessah, I.N. Tipping the Balance of Autism Risk: Potential Mechanisms Linking Pesticides and Autism. Environ. Health Perspect. 2012, 120, 944-951. [CrossRef] [PubMed]

27. Volk, H.E.; Hertz-Picciotto, I.; Delwiche, L.; Lurmann, F.; McConnell, R. Residential Proximity to Freeways and Autism in the CHARGE Study. Environ. Health Perspect. 2011, 119, 873-877. [CrossRef] [PubMed]

28. Siniscalco, D.; Cirillo, A.; Bradstreet, J.; Antonucci, N. Epigenetic findings in autism: New perspectives for therapy. Int. J. Environ. Res. Public Health 2013, 10, 4261-4273. [CrossRef] [PubMed] 
29. Birnbaum, L.S. State of the Science of Endocrine Disruptors. Environ. Health Perspect. 2013, 121. [CrossRef] [PubMed]

30. Zoeller, R.T.; Brown, T.R.; Doan, L.L.; Gore, A.C.; Skakkebaek, N.E.; Soto, A.M.; Woodruff, T.J.; Vom Saal, F.S. Endocrine-Disrupting Chemicals and Public Health Protection: A Statement of Principles from The Endocrine Society. Endocrinology 2012, 153, 4097-4110. [CrossRef] [PubMed]

31. World Health Organization; United Nations Environment Programme. State of the Science of Endocrine Disrupting Chemicals; United Nations Environment Programme and the World Health Organization: Geneva, Switzerland, 2012.

32. Brouwers, M.M.; van Tongeren, M.; Hirst, A.A.; Bretveld, R.W.; Roeleveld, N. Occupational exposure to potential endocrine disruptors: Further development of a job exposure matrix. Occup. Environ. Med. 2009, 66, 607-614. [CrossRef] [PubMed]

33. World Health Organization; International Labour Organisation; United Nations Environment Programme. Global Assessment of the State-of-the-Science of Endocrine Disruptors; World Health Organization: Geneva, Switzerland, 2002.

34. Goldman, L. New approaches for assessing the etiology and risks of developmental abnormalities from chemical exposure. Reprod. Toxicol. 1997, 11, 443-451. [CrossRef]

35. Sharara, F.I.; Seifer, D.B.; Flaws, J.A. Environmental toxicants and female reproduction 44Additional references are available from the authors. Fertil. Steril. 1998, 70, 613-622. [CrossRef]

36. Braun, J.M.; Yolton, K.; Stacy, S.L.; Erar, B.; Papandonatos, G.D.; Bellinger, D.C.; Lanphear, B.P.; Chen, A. Prenatal environmental chemical exposures and longitudinal patterns of child neurobehavior. NeuroToxicology 2017, 62, 192-199. [CrossRef] [PubMed]

37. Vrijheid, M.; Casas, M.; Gascon, M.; Valvi, D.; Nieuwenhuijsen, M. Environmental pollutants and child health-A review of recent concerns. Int. J. Hyg. Environ. Health 2016, 219, 331-342. [CrossRef] [PubMed]

38. Braun, J.M.; Yolton, K.; Dietrich, K.N.; Hornung, R.; Ye, X.; Calafat, A.M.; Lanphear, B.P. Prenatal Bisphenol A Exposure and Early Childhood Behavior. Environ. Health Perspect. 2009, 117, 1945-1952. [CrossRef] [PubMed]

39. Herbstman, J.B.; Kurzon, M.; Lederman, S.A.; Rauh, V.; Tang, D.; Perera, F. Prenatal PBDEs and Neurodevelopment: Herbstman et al. Respond to Goodman et al. and to Banasik and Strosznajder. Environ. Health Perspect. 2010, 118, a469-a470. [CrossRef]

40. Kim, Y.; Ha, E.; Kim, E.; Park, H.; Ha, M.; Kim, J.; Hong, Y.; Chang, N.; Kim, B. Prenatal Exposure to Phthalates and Infant Development at 6 Months: Prospective Mothers and Children's Environmental Health (MOCEH) Study. Environ. Health Perspect. 2011, 119, 1495-1500. [CrossRef] [PubMed]

41. Barker, D.J.P. Sir Richard Doll Lecture. Developmental origins of chronic disease. Public Health 2012, 126, 185-189. [CrossRef] [PubMed]

42. Heindel, J.J.; Balbus, J.; Birnbaum, L.; Brune-Drisse, M.N.; Grandjean, P.; Gray, K.; Landrigan, P.J.; Sly, P.D.; Suk, W.; Cory Slechta, D.; et al. Developmental Origins of Health and Disease: Integrating Environmental Influences. Endocrinology 2015, 156, 3416-3421. [CrossRef] [PubMed]

43. Adinolfi, M. The development of the human blood-CSF-brain barrier. Dev. Med. Child Neurol. 1985, 27, 532-537. [CrossRef] [PubMed]

44. Meeker, J.D. Exposure to Environmental Endocrine Disruptors and Child Development. Arch. Pediatr. Adolesc. Med. 2012, 166. [CrossRef] [PubMed]

45. Moosa, A.; Shu, H.; Sarachana, T.; Hu, V.W. Are endocrine disrupting compounds environmental risk factors for autism spectrum disorder? Horm. Behav. 2018, 101, 13-21. [CrossRef] [PubMed]

46. Palanza, P.; Morellini, F.; Parmigiani, S.; vom Saal, F. Prenatal exposure to endocrine disrupting chemicals: Effects on behavioral development. Neurosci. Biobehav. Rev. 1999, 23, 1011-1027. [CrossRef]

47. Sadler, T. Langman's Medical Embryology, 12th ed.; Lippincott Williams \& Wilkins: Baltimore, MD, USA, 2011.

48. Andersen, H.R.; Nielsen, J.B.; Grandjean, P. Toxicologic evidence of developmental neurotoxicity of environmental chemicals. Toxicology 2000, 144, 121-127. [CrossRef]

49. Sakamoto, M.; Kubota, M.; Liu, X.J.; Murata, K.; Nakai, K.; Satoh, H. Maternal and Fetal Mercury andn-3 Polyunsaturated Fatty Acids as a Risk and Benefit of Fish Consumption to Fetus. Environ. Sci. Technol. 2004, 38, 3860-3863. [CrossRef] [PubMed]

50. Hakkola, J.; Tanaka, E.; Pelkonen, O. Developmental Expression of Cytochrome P450 Enzymes in Human Liver. Pharmacol. Toxicol. 1998, 82, 209-217. [CrossRef] [PubMed] 
51. Koufaris, C.; Sismani, C. Modulation of the Genome and Epigenome of Individuals Susceptible to Autism by Environmental Risk Factors. Int. J. Mol. Sci. 2015, 16, 8699-8718. [CrossRef] [PubMed]

52. Matelski, L.; Van de Water, J. Risk factors in autism: Thinking outside the brain. J. Autoimmun. 2016, 67, 1-7. [CrossRef] [PubMed]

53. Prusinski, L.; Al-Hendy, A.; Yang, Q. Developmental Exposure to Endocrine Disrupting Chemicals Alters the Epigenome: Identification of Reprogrammed Targets. Gynecol. Obstet. Res. Open J. 2016, 3, 1-6. [CrossRef] [PubMed]

54. Schug, T.T.; Blawas, A.M.; Gray, K.; Heindel, J.J.; Lawler, C.P. Elucidating the Links Between Endocrine Disruptors and Neurodevelopment. Endocrinology 2015, 156, 1941-1951. [CrossRef] [PubMed]

55. Sealey, L.A.; Hughes, B.W.; Sriskanda, A.N.; Guest, J.R.; Gibson, A.D.; Johnson-Williams, L.; Pace, D.G.; Bagasra, O. Environmental factors in the development of autism spectrum disorders. Environ. Int. 2016, 88, 288-298. [CrossRef] [PubMed]

56. Craig, Z.R.; Wang, W.; Flaws, J.A. Endocrine-disrupting chemicals in ovarian function: Effects on steroidogenesis, metabolism and nuclear receptor signaling. Reproduction 2011, 142, 633-646. [CrossRef] [PubMed]

57. Ghisari, M.; Bonefeld-Jorgensen, E.C. Effects of plasticizers and their mixtures on estrogen receptor and thyroid hormone functions. Toxicol. Lett. 2009, 189, 67-77. [CrossRef] [PubMed]

58. Hernandez, M.E.; Gore, A.C. Endocrine disruptors: Chemical contaminants-A toxic mixture for neurodevelopment. Nat. Rev. Endocrinol. 2017, 13, 322-323. [CrossRef] [PubMed]

59. Lanphear, B.P.; Hornung, R.; Khoury, J.; Yolton, K.; Baghurst, P.; Bellinger, D.C.; Canfield, R.L.; Dietrich, K.N.; Bornschein, R.; Greene, T.; et al. Low-Level Environmental Lead Exposure and Children's Intellectual Function: An International Pooled Analysis. Environ. Health Perspect. 2005, 113, 894-899. [CrossRef] [PubMed]

60. Axelrad, D.A.; Bellinger, D.C.; Ryan, L.M.; Woodruff, T.J. Dose-Response Relationship of Prenatal Mercury Exposure and IQ: An Integrative Analysis of Epidemiologic Data. Environ. Health Perspect. 2007, 115, 609-615. [CrossRef] [PubMed]

61. Hoover, R.N.; Hyer, M.; Pfeiffer, R.M.; Adam, E.; Bond, B.; Cheville, A.L.; Colton, T.; Hartge, P.; Hatch, E.E.; Herbst, A.L.; et al. Adverse Health Outcomes in Women Exposed in Utero to Diethylstilbestrol. N. Engl. J. Med. 2011, 365, 1304-1314. [CrossRef] [PubMed]

62. Eubig, P.A.; Aguiar, A.; Schantz, S.L. Lead and PCBs as Risk Factors for Attention Deficit/Hyperactivity Disorder. Environ. Health Perspect. 2010, 118, 1654-1667. [CrossRef] [PubMed]

63. Eskenazi, B.; Marks, A.R.; Bradman, A.; Fenster, L.; Johnson, C.; Barr, D.B.; Jewell, N.P. In Utero Exposure to Dichlorodiphenyltrichloroethane (DDT) and Dichlorodiphenyldichloroethylene (DDE) and Neurodevelopment Among Young Mexican American Children. Pediatrics 2006, 118, 233-241. [CrossRef] [PubMed]

64. Rauh, V.A.; Garfinkel, R.; Perera, F.P.; Andrews, H.F.; Hoepner, L.; Barr, D.B.; Whitehead, R.; Tang, D.; Whyatt, R.W. Impact of Prenatal Chlorpyrifos Exposure on Neurodevelopment in the First 3 Years of Life Among Inner-City Children. Pediatrics 2006, 118, e1845-e1859. [CrossRef] [PubMed]

65. Gore, A.C.; Martien, K.M.; Gagnidze, K.; Pfaff, D. Implications of Prenatal Steroid Perturbations for Neurodevelopment, Behavior, and Autism. Endocr. Rev. 2014, 35, 961-991. [CrossRef] [PubMed]

66. Baron-Cohen, S.; Knickmeyer, R.; Belmonte, M. Sex Differences in the Brain: Implications for Explaining Autism. Science 2005, 310, 819-823. [CrossRef] [PubMed]

67. Baron-Cohen, S.; Auyeung, B.; Nørgaard-Pedersen, B.; Hougaard, D.M.; Abdallah, M.W.; Melgaard, L.; Cohen, A.S.; Chakrabarti, B.; Ruta, L.; Lombardo, M.V. Elevated fetal steroidogenic activity in autism. Mol. Psychiatry 2014, 20, 369-376. [CrossRef] [PubMed]

68. Braun, J.M. Endocrine disrupting compounds, gonadal hormones, and autism. Dev. Med. Child Neurol. 2012, 54, 1068. [CrossRef] [PubMed]

69. Khan, A.; Harney, J.W.; Zavacki, A.M.; Sajdel-Sulkowska, E.M. Disrupted brain thyroid hormone homeostasis and altered thyroid hormone-dependent brain gene expression in autism spectrum disorders. J. Physiol. Pharmacol. 2014, 65, 257-272. [PubMed]

70. Andersen, S.; Laurberg, P.; Wu, C.; Olsen, J. Attention deficit hyperactivity disorder and autism spectrum disorder in children born to mothers with thyroid dysfunction: A Danish nationwide cohort study. BJOG Int. J. Obstet. Gynaecol. 2014, 121, 1365-1374. [CrossRef] [PubMed] 
71. Chevrier, J.; Gunier, R.B.; Bradman, A.; Holland, N.T.; Calafat, A.M.; Eskenazi, B.; Harley, K.G. Maternal Urinary Bisphenol A during Pregnancy and Maternal and Neonatal Thyroid Function in the CHAMACOS Study. Environ. Health Perspect. 2013, 121, 138-144. [CrossRef] [PubMed]

72. Johns, L.E.; Ferguson, K.K.; Soldin, O.P.; Cantonwine, D.E.; Rivera-González, L.O.; Del Toro, L.V.; Calafat, A.M.; Ye, X.; Alshawabkeh, A.N.; Cordero, J.F.; et al. Urinary phthalate metabolites in relation to maternal serum thyroid and sex hormone levels during pregnancy: A longitudinal analysis. Reprod. Biol. Endocrinol. 2015, 13, 4. [CrossRef] [PubMed]

73. Skinner, M.K.; Anway, M.D.; Savenkova, M.I.; Gore, A.C.; Crews, D. Transgenerational Epigenetic Programming of the Brain Transcriptome and Anxiety Behavior. PLoS ONE 2008, 3, e3745. [CrossRef] [PubMed]

74. Woodruff, T.J.; Sutton, P. An Evidence-Based Medicine Methodology to Bridge The Gap Between Clinical And Environmental Health Sciences. Health Aff. 2011, 30, 931-937. [CrossRef] [PubMed]

75. Woodruff, T.J.; Sutton, P. The Navigation Guide Systematic Review Methodology: A Rigorous and Transparent Method for Translating Environmental Health Science into Better Health Outcomes. Environ. Health Perspect. 2014, 122, 1007-1014. [CrossRef] [PubMed]

76. Atkins, D.; Best, D.; Briss, P.A.; Eccles, M.; Falck-Ytter, Y.; Flottorp, S.; Guyatt, G.H.; Harbour, R.T.; Haugh, M.; Henry, D.; GRADE Working Group. Grading quality of evidence and strength of recommendations. BMJ 2004, 328, 1490. [CrossRef] [PubMed]

77. Atkins, D.; Eccles, M.; Flottorp, S.; Guyatt, G.H.; Henry, D.; Hill, S.; Liberati, A.; O'Connell, D.; Oxman, A.D.; Phillips, B.; et al. Systems for grading the quality of evidence and the strength of recommendations I: Critical appraisal of existing approaches The GRADE Working Group. BMC Health Serv. Res. 2004, 4, 38. [CrossRef] [PubMed]

78. Balshem, H.; Helfand, M.; Schünemann, H.J.; Oxman, A.D.; Kunz, R.; Brozek, J.; Vist, G.E.; Falck-Ytter, Y.; Meerpohl, J.; Norris, S. GRADE guidelines: 3. Rating the quality of evidence. J. Clin. Epidemiol. 2011, 64, 401-406. [CrossRef] [PubMed]

79. Guyatt, G.H.; Oxman, A.D.; Kunz, R.; Atkins, D.; Brozek, J.; Vist, G.; Alderson, P.; Glasziou, P.; Falck-Ytter, Y.; Schünemann, H.J. GRADE guidelines: 2. Framing the question and deciding on important outcomes. J. Clin. Epidemiol. 2011, 64, 395-400. [CrossRef] [PubMed]

80. Guyatt, G.; Oxman, A.D.; Akl, E.A.; Kunz, R.; Vist, G.; Brozek, J.; Norris, S.; Falck-Ytter, Y.; Glasziou, P.; deBeer, H. GRADE guidelines: 1. Introduction-GRADE evidence profiles and summary of findings tables. J. Clin. Epidemiol. 2011, 64, 383-394. [CrossRef] [PubMed]

81. Higgins, J.; Green, S. (Eds.) Cochrane Handbook for Systematic Reviews of Interventions; John Wiley \& Sons: Hoboken, NJ, USA, 2008.

82. National Research Council. Science and Decisions: Advancing Risk Assessment; National Academies Press: Washington, DC, USA, 2009.

83. Viswanathan, M.; Patnode, C.D.; Berkman, N.D.; Bass, E.B.; Chang, S.; Hartling, L.; Murad, M.H.; Treadwell, J.R.; Kane, R.L. Assessing the Risk of Bias of Individual Studies in Systematic Reviews of Health Care Interventions; Agency for Healthcare Research and Quality: Rockville, MD, USA, 2012.

84. Friedenreich, C.M. Methods for Pooled Analyses of Epidemiologic Studies. Epidemiology 1993, 4, $295-302$. [CrossRef] [PubMed]

85. Froom, P.; Froom, J. Deficiencies in structured medical abstracts. J. Clin. Epidemiol. 1993, 46, 591-594. [CrossRef]

86. Liberati, A.; Altman, D.G.; Tetzlaff, J.; Mulrow, C.; Gøtzsche, P.C.; Ioannidis, J.P.A.; Clarke, M.; Devereaux, P.J.; Kleijnen, J.; Moher, D. The PRISMA Statement for Reporting Systematic Reviews and Meta-Analyses of Studies That Evaluate Health Care Interventions: Explanation and Elaboration. PLoS Med. 2009, 6, e1000100. [CrossRef] [PubMed]

87. Centers for Disease Control and Prevention. Prevalence of autism spectrum disorders-Autism and developmental disabilities monitoring network, 14 sites, United States, 2002. MMWR Surveill. Summ. 2007, 56, 12-28.

88. Centers for Disease Control and Prevention. Prevalence of Autism Spectrum Disorders-Autism and Developmental Disabilities Monitoring Network, 14 Sites, United States, 2008. MMWR Surveill. Summ. 2012, 61, 1-19. 
89. American Psychiatric Association. Diagnostic and Statistical Manual of Mental Disorders, 4th ed.; Text Revised DSM-IV-TR; American Psychiatric Association: Washington, DC, USA, 2000.

90. American Psychiatric Association. Diagnostic and Statistical Manual of Mental Disorders, 5th ed.; DSM-V; American Psychiatric Association: Washington, DC, USA, 2013.

91. Bölte, S.; Poustka, F.; Constantino, J.N. Assessing autistic traits: Cross-cultural validation of the social responsiveness scale (SRS). Autism Res. 2008, 1, 354-363. [CrossRef] [PubMed]

92. Constantino, J.N.; Davis, S.A.; Todd, R.D.; Schindler, M.K.; Gross, M.M.; Brophy, S.L.; Metzger, L.M.; Shoushtari, C.S.; Splinter, R.; Reich, W. Validation of a Brief Quantitative Measure of Autistic Traits: Comparison of the Social Responsiveness Scale with the Autism Diagnostic Interview-Revised. J. Autism Dev. Disord. 2003, 33, 427-433. [CrossRef] [PubMed]

93. Vandenbroucke, J.P. Strengthening the Reporting of Observational Studies in Epidemiology (STROBE): Explanation and Elaboration. Ann. Intern. Med. 2007, 147. [CrossRef] [PubMed]

94. Larsson, M.; Weiss, B.; Janson, S.; Sundell, J.; Bornehag, C.-G. Associations between indoor environmental factors and parental-reported autistic spectrum disorders in children 6-8 years of age. Neurotoxicology 2009, 30, 822-831. [CrossRef] [PubMed]

95. McCanlies, E.C.; Fekedulegn, D.; Mnatsakanova, A.; Burchfiel, C.M.; Sanderson, W.T.; Charles, L.E.; Hertz-Picciotto, I. Parental Occupational Exposures and Autism Spectrum Disorder. J. Autism Dev. Disord. 2012, 42, 2323-2334. [CrossRef] [PubMed]

96. Roberts, A.L.; Lyall, K.; Hart, J.E.; Laden, F.; Just, A.C.; Bobb, J.F.; Koenen, K.C.; Ascherio, A.; Weisskopf, M.G. Perinatal Air Pollutant Exposures and Autism Spectrum Disorder in the Children of Nurses' Health Study II Participants. Environ. Health Perspect. 2013, 121, 978-984. [CrossRef] [PubMed]

97. Windham, G.C.; Zhang, L.; Gunier, R.; Croen, L.A.; Grether, J.K. Autism Spectrum Disorders in Relation to Distribution of Hazardous Air Pollutants in the San Francisco Bay Area. Environ. Health Perspect. 2006, 114, 1438-1444. [CrossRef] [PubMed]

98. Windham, G.C.; Sumner, A.; Li, S.X.; Anderson, M.; Katz, E.; Croen, L.A.; Grether, J.K. Use of Birth Certificates to Examine Maternal Occupational Exposures and Autism Spectrum Disorders in Offspring. Autism Res. 2013, 6, 57-63. [CrossRef] [PubMed]

99. Roberts, E.; English, P.; Grether, J.; Windham, G.; Somberg, L. Maternal Residence Near Agricultural Pesticide Applications and Autism Among Children in the California Central Valley. Epidemiology 2007, 18, S52. [CrossRef]

100. Shelton, J.F.; Geraghty, E.M.; Tancredi, D.J.; Delwiche, L.D.; Schmidt, R.J.; Ritz, B.; Hansen, R.L.; Hertz-Picciotto, I. Neurodevelopmental Disorders and Prenatal Residential Proximity to Agricultural Pesticides: The CHARGE Study. Environ. Health Perspect. 2014, 122, 1103-1109. [CrossRef] [PubMed]

101. Talbott, E.O.; Marshall, L.P.; Rager, J.R.; Arena, V.C.; Sharma, R.K.; Stacy, S.L. Air toxics and the risk of autism spectrum disorder: The results of a population based case-control study in southwestern Pennsylvania. Environ. Health 2015, 14. [CrossRef] [PubMed]

102. Von Ehrenstein, O.S.; Aralis, H.; Cockburn, M.; Ritz, B. In Utero Exposure to Toxic Air Pollutants and Risk of Childhood Autism. Epidemiology 2014, 25, 851-858. [CrossRef] [PubMed]

103. Miodovnik, A.; Engel, S.M.; Zhu, C.; Ye, X.; Soorya, L.V.; Silva, M.J.; Calafat, A.M.; Wolff, M.S. Endocrine disruptors and childhood social impairment. Neurotoxicology 2011, 32, 261-267. [CrossRef] [PubMed]

104. Nowack, N.; Wittsiepe, J.; Kasper-Sonnenberg, M.; Wilhelm, M.; Schölmerich, A. Influence of Low-Level Prenatal Exposure to PCDD/Fs and PCBs on Empathizing, Systemizing and Autistic Traits: Results from the Duisburg Birth Cohort Study. PLoS ONE 2015, 10, e0129906. [CrossRef] [PubMed]

105. Cheslack-Postava, K.; Rantakokko, P.V.; Hinkka-Yli-Salomäki, S.; Surcel, H.-M.; McKeague, I.W.; Kiviranta, H.A.; Sourander, A.; Brown, A.S. Maternal serum persistent organic pollutants in the Finnish Prenatal Study of Autism: A pilot study. Neurotoxicol. Teratol. 2013, 38, 1-5. [CrossRef] [PubMed]

106. Liew, Z.; Ritz, B.; von Ehrenstein, O.S.; Bech, B.H.; Nohr, E.A.; Fei, C.; Bossi, R.; Henriksen, T.B.; Bonefeld-Jørgensen, E.C.; Olsen, J. Attention Deficit/Hyperactivity Disorder and Childhood Autism in Association with Prenatal Exposure to Perfluoroalkyl Substances: A Nested Case-Control Study in the Danish National Birth Cohort. Environ. Health Perspect. 2015, 123, 367-373. [CrossRef] [PubMed]

107. Guyatt, G.H.; Oxman, A.D.; Sultan, S.; Glasziou, P.; Akl, E.A.; Alonso-Coello, P.; Atkins, D.; Kunz, R.; Brozek, J.; Montori, V.; et al. GRADE guidelines: 9. Rating up the quality of evidence. J. Clin. Epidemiol. 2011, 64, 1311-1316. [CrossRef] [PubMed] 
108. Johnson, P.I.; Sutton, P.; Atchley, D.S.; Koustas, E.; Lam, J.; Sen, S.; Robinson, K.A.; Axelrad, D.A.; Woodruff, T.J. The Navigation Guide-Evidence-Based Medicine Meets Environmental Health: Systematic Review of Human Evidence for PFOA Effects on Fetal Growth. Environ. Health Perspect. 2014, 122, 1028-1039. [CrossRef] [PubMed]

109. Johnson, P.I.; Sutton, P.; Koustas, E.; Vesterinen, H.M.; Woodruff, T.J. Response to correspondence by Heather Lynch, Julie Goodman and Nancy Beck Re: “Application of the Navigation Guide systematic review methodology to the evidence for developmental and reproductive toxicity of triclosan". Environ. Int. 2017, 102, 76-78. [CrossRef] [PubMed]

110. Koustas, E.; Lam, J.; Sutton, P.; Johnson, P.I.; Atchley, D.S.; Sen, S.; Robinson, K.A.; Axelrad, D.A.; Woodruff, T.J. The Navigation Guide-Evidence-Based Medicine Meets Environmental Health: Systematic Review of Nonhuman Evidence for PFOA Effects on Fetal Growth. Environ. Health Perspect. 2014, 122, 1015-1027. [CrossRef] [PubMed]

111. Lam, J.; Koustas, E.; Sutton, P.; Johnson, P.I.; Atchley, D.S.; Sen, S.; Robinson, K.A.; Axelrad, D.A.; Woodruff, T.J. The Navigation Guide-Evidence-Based Medicine Meets Environmental Health: Integration of Animal and Human Evidence for PFOA Effects on Fetal Growth. Environ. Health Perspect. 2014, 122, 1040-1051. [CrossRef] [PubMed]

112. Lam, J.; Sutton, P.; Kalkbrenner, A.; Windham, G.; Halladay, A.; Koustas, E.; Lawler, C.; Davidson, L.; Daniels, N.; Newschaffer, C.; et al. A Systematic Review and Meta-Analysis of Multiple Airborne Pollutants and Autism Spectrum Disorder. PLoS ONE 2016, 11, e0161851. [CrossRef] [PubMed]

113. Vesterinen, H.M.; Johnson, P.I.; Atchley, D.S.; Sutton, P.; Lam, J.; Zlatnik, M.G.; Sen, S.; Woodruff, T.J. Fetal growth and maternal glomerular filtration rate: A systematic review. J. Matern.-Fetal Neonatal Med. 2015, 28, 2176-2181. [CrossRef] [PubMed]

114. He, J.; Yang, D.; Wang, C.; Liu, W.; Liao, J.; Xu, T.; Bai, C.; Chen, J.; Lin, K.; Huang, C.; et al. Chronic zebrafish low dose decabrominated diphenyl ether (BDE-209) exposure affected parental gonad development and locomotion in F1 offspring. Ecotoxicology 2011, 20, 1813-1822. [CrossRef] [PubMed]

115. Frye, C.; Bo, E.; Calamandrei, G.; Calzà, L.; Dessì-Fulgheri, F.; Fernández, M.; Fusani, L.; Kah, O.; Kajta, M.; Le Page, Y.; et al. Endocrine Disrupters: A Review of Some Sources, Effects, and Mechanisms of Actions on Behaviour and Neuroendocrine Systems. J. Neuroendocrinol. 2011, 24, 144-159. [CrossRef] [PubMed]

116. Ghosh, S.; Mitra, P.S.; Loffredo, C.A.; Trnovec, T.; Murinova, L.; Sovcikova, E.; Ghimbovschi, S.; Zang, S.; Hoffman, E.P.; Dutta, S.K. Transcriptional profiling and biological pathway analysis of human equivalence PCB exposure in vitro: Indicator of disease and disorder development in humans. Environ. Res. 2015, 138, 202-216. [CrossRef] [PubMed]

117. Ciernia, A.V.; LaSalle, J. The landscape of DNA methylation amid a perfect storm of autism aetiologies. Nat. Rev. Neurosci. 2016, 17, 411-423. [CrossRef] [PubMed]

118. Sun, W.; Poschmann, J.; Cruz-Herrera del Rosario, R.; Parikshak, N.N.; Hajan, H.S.; Kumar, V.; Ramasamy, R.; Belgard, T.G.; Elanggovan, B.; Wong, C.C.Y.; et al. Histone Acetylome-wide Association Study of Autism Spectrum Disorder. Cell 2016, 167, 1385-1397.e11. [CrossRef] [PubMed]

119. Schumann, C.M.; Sharp, F.R.; Ander, B.P.; Stamova, B. Possible sexually dimorphic role of miRNA and other sncRNA in ASD brain. Mol. Autism 2017, 8. [CrossRef] [PubMed]

120. Wu, Y.E.; Parikshak, N.N.; Belgard, T.G.; Geschwind, D.H. Genome-wide, integrative analysis implicates microRNA dysregulation in autism spectrum disorder. Nat. Neurosci. 2016, 19, 1463-1476. [CrossRef] [PubMed]

121. Skinner, M.K.; Savenkova, M.I.; Zhang, B.; Gore, A.C.; Crews, D. Gene bionetworks involved in the epigenetic transgenerational inheritance of altered mate preference: Environmental epigenetics and evolutionary biology. BMC Genom. 2014, 15, 377. [CrossRef] [PubMed]

122. Siu, M.T.; Weksberg, R. Epigenetics of Autism Spectrum Disorder. Adv. Exp. Med. Biol. 2017, 63-90. [CrossRef]

(C) 2018 by the authors. Licensee MDPI, Basel, Switzerland. This article is an open access article distributed under the terms and conditions of the Creative Commons Attribution (CC BY) license (http:/ / creativecommons.org/licenses/by/4.0/). 